\title{
1 From ice to penguins: the role of 2 mathematics in Antarctic research
}

\section{3}

4 José C. Xavier ${ }^{1,2}$, S.L. Hill ${ }^{2}$, M. Belchier ${ }^{2}$, T. J. Bracegirdle ${ }^{2}$, E. J. 5 Murphy $^{2}$ \& J. Lopes-Dias ${ }^{3}$

1- Institute of Marine Research (IMAR-CMA), Department of Life Sciences, University of Coimbra, 3001-401 Coimbra, Portugal

2- British Antarctic Survey (BAS), Natural Environment Research Council, High Cross, Madingley Road, Cambridge, CB3 0ET, UK

3- Lisbon School of Economics and Management (ISEG), Technical University of Lisbon, Rua do Quelhas, 6, 1200-781 Lisbon, Portugal

\begin{abstract}
Mathematics underpins all modern Antarctic science as illustrated by numerous activities carried out during the international year "Mathematics for Planet Earth". Here, we provide examples of some ongoing applications of mathematics in a wide range of Antarctic science disciplines: 1. Feeding and foraging of marine predators; 2. Fisheries management and ecosystem modeling; and 3. Climate change research. Mathematics has allowed the development of diverse models of physical and ecological processes in the Antarctic. It has provided insights into the past dynamics of these systems and allows projections of potential future conditions, which are essential for understanding and managing the effects of fishing and climate change. Highly specific methods and models have been developed to address particular questions in each discipline, from the detailed analyses of remote-sensed predator tracking data to the assessment of the outputs from multiple global climate models. A key issue, that is common to all disciplines, is how to deal with the inherent uncertainty that arises from limited data availability and the assumptions or simplifications that are necessary in the analysis and modeling of interacting processes. With the continued rapid development of satellite-based and remote observation systems (e.g. ocean drifters and automatic weather stations), and of new methods for genetic analyses of biological systems, a step-change is occurring in the
\end{abstract}


magnitude of data available on all components of Antarctic systems. These changes in data availability have already led to the development of new methods and algorithms for their efficient collection, validation, storage and analysis. Further progress will require the development of a wide range of new and innovative mathematical approaches, continuing the trend of world science becoming increasingly international and interdisciplinary.

\section{Introduction}

The Polar Regions are the cornerstones of the global ecosystem, barometers of the health of the planet, and messengers of global processes (IPCC 2007; Krupnik et al. 2011). Because it strongly influences the global climate and harbours unique and diverse biological communities, the Antarctic plays a distinct and critical role in both the physical Earth system and the ecosystem that it supports (Constable et al. in press; Kennicutt et al. in press-a; Kennicutt et al. in press-b). Antarctica is renowned as being the highest (i.e. on average the height of the continent is approx. 2300 meters height), driest, windiest and coldest continent, boasting the lowest recorded temperature on Earth, $-93.2^{\circ} \mathrm{C}$, on the East Antarctic Plateau (http://www.nasa.gov/press/2013/december/nasa-usgs-landsat-8-satellite-pinpointscoldest-spots-on-earth/\#.UqndqvvwoYt, accessed 12/12/13), but it is surrounded by the Southern Ocean (described here as waters south of the Antarctic Polar front; Figure 2) which, in contrast, is very thermally stable (with some locations varying as little as $0.2^{\circ} \mathrm{C}$ over a year) (Convey et al. 2012).

Some of the key science on globally important issues is conducted in the Antarctic, often coordinated by the Scientific Committee on Antarctic Research and various the bodies that administer the Antarctic Treaty System. These issues include sea level rise, climate change, ocean acidification, biodiversity change, the ozone hole and global ocean circulation (Sarmiento et al. 2004; Orr et al. 2005; Smetacek,Nicol 2005; Anisimov et al. 2007; Rignot et al. 2008; Turner et al. 2009; Krupnik et al. 2011; Convey et al. 2012; Turner et al. 2013a).

Furthermore, the Antarctic continues to spark the curiosity and imagination of people around the world. It appeals to the sense of adventure and fear of the unknown. These are perfect ingredients for education and outreach (Kaiser et al. 2010; Walton 
1 2013; Walton et al. 2013; Xavier et al. 2013a), providing an excellent way to transmit

2 basic concepts about a wide range of Science, Technology, Engineering and

3 Mathematics (STEM) disciplines.

During the international year "Mathematics for Planet Earth", numerous activities related to mathematics were carried out throughout the world, including the

6 International Conference and Advanced School Planet Earth, Mathematics of Energy

7 and Climate Change, held in Lisbon (Portugal), in 21-28 March 2013. Here, we

8 follow discussions at that conference with a selective review of how mathematics is 9 applied in a wide range of Antarctic science disciplines.

\section{The scope of mathematical analyses in Antarctic science}

Mathematics plays an essential role in all modern Antarctic science. It is central to of the data collection process, for example in generating efficient algorithms to allow data storage and transfer, and for the calibration and validation of data from in-situ and remote instrumentation (e.g. automatic weather stations and satellite-based instruments). Mathematics is used in analyses and modeling of all aspects of Antarctic science including weather and climate, ice sheet and sea ice dynamics, ocean circulation, biogeochemical cycles and ecosystem processes. A key challenge at present is in determining the impacts of climate change on, in particular, ecosystem dynamics or glaciological change. To make progress there will need to be improvements in climate modeling of sub-regions of Antarctica, in particular the algorithms that are used to represent clouds, ocean/ice dynamics and ecosystemclimate interactions. Improvements will require both updated mathematical models and, possibly equally importantly, observations with which to calibrate models. A key example is the Antarctic Peninsula, where the steep mountains are difficult to represent in climate models with clear implications for assessing wider impacts of climate change in the region. The range and complexity of applications is wide, from simple analyses of small scale experiments to high resolution satellite-based studies that provide circumpolar views, and from simple theoretical to fully coupled atmosphere-ocean-ice models. Here, we illustrate the development and application of mathematical analyses by considering three major areas of Antarctic science: 1 . Feeding and foraging of marine top predators; 2. Fisheries management and ecosystem modeling; and 3. Climate change research. These sections provide illustrations in three distinct types of scientific activity. Studies of the feeding and 
1 foraging of marine top predators are strongly field based and require extensive sample collection and analysis and careful design of sampling methods. With the advent of satellite instrumentation, remote tracking now provides high resolution information on position and movement, which has revolutionized analyses of predator foraging. This has been associated with the development of a range of other remote devices, and has generated a step-change in the size of datasets available. The second area, fisheries management and ecosystem modeling, provides an illustration of the use of mathematical methods in an applied arena to generate robust policy advice. The final area, climate change, illustrates the challenge of developing projections of the impacts of future change that can only be addressed through mathematical analysis and modeling. essential to understand what animals eat and where they feed. To obtain reliable estimates from the available data requires a wide range of mathematical (particularly statistical and modeling) tools The most common source of feeding data is the stomach contents of sampled predators. To characterize the diet of top predators, such as penguins (Figure 1) or albatrosses, prey in these stomach contents are generally quantified by their frequency of occurrence, or the number or mass of each prey species (Xavier et al. 2003a; Ratcliffe,Trathan 2011). To identify the prey (generally fish, cephalopods such as squid and octopods, and crustaceans), scientists often have to use hard structures that are not destroyed by digestion. These structures include the sagittae otoliths (colloquially the "ear bones") of fish. Otoliths are calcium carbonate structures located directly behind the brain of teleost (bony) fish. For crustaceans, scientists use their carapaces and for cephalopods their beaks. Cephalopod beaks are chitinous structures, whose function is similar to that of teeth in carnivorous mammals: to grasp, kill and dismember their prey.

Allometric regression equations can be derived to describe the relationship between the mass and length of complete individuals of known species and the size of 
1 contents these equations provide a valuable mathematical tool for reconstructing what

2 a predator has been consuming (Hecht 1987; Reid 1996; Boltovskoy 1999;

3 Xavier,Cherel 2009). However, allometric equations are not available for numerous

4 species because they are still poorly known" (therefore scientists must rely on

5 equations from closely related species) and many of the available allometric equations

6 are based on a limited number and size range of specimens. Therefore, future work

7 must focus on obtaining more complete fish, crustaceans and cephalopods to improve

8 allometric equations, and on characterizing the uncertainty that is inherent in the

9 application of such methods (Xavier et al. 2003a; Xavier et al. 2005; Xavier et al.

10 2007; Xavier et al. 2011; Xavier et al. 2013b; Xavier et al. in press).

11 One of the key issues that marine ecologists need to address, when assessing

12 the diet and feeding ecology of a predator, is how many samples are needed. This

13 issue is particularly important as some predators can cover great distances, feed in

14 different regions (e.g. Wandering albatrosses Diomedea exulans can forage in

15 Antarctic, sub-Antarctic and subtropical waters during their breeding period, while

16 grey-headed albatrosses Thalassarche chrysostoma can go around the Antarctic

17 continent during their non breeding period) at different times of the year (Xavier et al.

18 2003b; Xavier et al. 2004; Croxall et al. 2005; Xavier et al. 2006). Therefore, it is

19 essential to characterize their diet correctly, and so to provide fundamental data for

20 food web studies, particularly modeling the present ecosystem status and predicting

21 future changes. Mathematically, this is an interesting challenge. A randomization

22 technique was used to estimate the number of stomach samples from albatrosses

23 needed to reach two saturation points: (1) the maximum cumulative number of

24 species; and (2) where each of the five most important species (i.e. $>5 \%$ of the diet,

25 by mass) was present in at least one sample (Xavier et al. 2005). For each sampling

26 event, the program randomly selected one of the samples and checked the species

27 present. If one or more of the required species were absent, the program randomly

28 selected another sample that had not yet been selected, and the process was repeated

29 until one of the two saturation points was reached. The entire process was repeated

30100 times. This study also compared different ways of collecting samples (i.e. using

31 stomach contents or voluntary regurgitations, named boluses) which permitted the

32 investigation of biases associated with each sampling method (Xavier et al. 2005).

33 Other techniques for analyzing diet use tissues from stomach samples to

34 identify prey species, or from predators (e.g. flesh, feathers, blood) to identify their 
1 habitat or trophic level (e.g. DNA analyses, stable isotopes, fatty acids, trace

2 elements, chemical pollutants) with considerable success (Cherel,Hobson 2005;

3 Deagle et al. 2007; Karnovsky et al. 2012; Ramos,Gonzalez-Solis 2012; Tavares et al. 2013). Each of these techniques involves its own unique analytical challenges. Mixed data sources (e.g. diet data obtained from stomach contents and data on the stable isotope signatures from predators and prey) can be compared to calibrate different methods. A Bayesian multisource stable isotope mixing model (SIAR: Stable Isotope Analyses in the statistical package R) has been used to estimate the probable contributions of each prey to the diet of each individual and hence the predator's level of specialization on particular prey items (Parnell et al. 2010). This method indicated that for wandering albatrosses Diomedea exulans fish was the main component (56.4\%) of the diet, followed by cephalopods (43.6 \%). These proportions were similar to those from analysis of stomach contents, showing the usefulness of these models for future research (Ceia et al. 2012).

Advances in micro-technology (and the decreasing of the size of tracking devices) in the last two decades have revolutionized our understanding of the foraging behavior of predators (Phillips et al. 2003; Phillips et al. 2008; Block et al. 2011; Hazen et al. 2013). Seabirds can travel great distances (hundreds to thousands of kilometres) and exhibit a number of unique physiological adaptations for such highly pelagic lifestyles (Egevang et al. 2010). Albatrosses and petrels spend the great majority of their lives at sea, and the use of tracking technology is the most effective and, in many respects the only, means for gaining detailed insights into their foraging behaviour (Parmelee et al. 1985; Jouventin,Weimerskirch 1990; Prince et al. 1992).

Satellite sensors, combined with 'ground truth' data from in situ surveys, are contributing to a better understanding of ocean systems by providing large scale and long-term data on biological bulk parameters such as chlorophyll, and on ecologically relevant physical parameters, such as sea surface temperature or ice cover (Turner et al. 2009). These data, combined with tracking technology can be used to answer scientific questions about foraging behavior and how animals use their ocean habitat. For example, satellite-tracking on animals in the late 1990s involved the deployment of a Platform Terminal Transmitter (PTT) that sends a short radio signal typically every $90 \mathrm{~s}$ to polar-orbiting NOAA satellites. The precision of the location estimate can vary from meters to hundred of meters, depending on the number of satellites in view at that place and time, the design and power of the transmitter, and the speed of 
1 the animal (Wilson et al. 2002). More recently, Global Positioning System (GPS)

2 loggers have been widely used, mostly because of their higher precision (within $10 \mathrm{~m}$ )

3 (Weimerskirch et al. 2002) and ability to record positions at various time intervals,

4 from minutes to days (depending on the amount of time the device is on) (Nevitt et al.

5 2008). However, if scientists are more interested in knowing where animals are for a

6 longer period of time (e.g. large migration studies), geolocators or Global Location

7 Sensing (GLS) loggers are extremely useful (Phillips et al. 2004; Croxall et al. 2005).

8 GLS loggers record ambient light. This allows the estimation of sunset and sunrise

9 times from curve thresholds. These times in turn allow the estimation of latitude from

10 day length, following standard astronomical algorithms, and longitude from the time

11 of local mid-day with respect to GMT and Julian day. The disadvantages are that the

12 animal must be recaptured (as with most GPS loggers), only two locations can be

13 calculated per day, latitude estimation is impossible for variable periods around the

14 equinoxes, and the precision is relatively low, with an average error of $186 \mathrm{~km}$

15 estimated for free-ranging albatrosses (Phillips et al. 2004).

16 These examples demonstrate that the reliable estimation of animal location,

17 and its associated error, is a fundamental part of modern animal ecology. There are

18 many existing techniques for handling location error, but these are often ad hoc or are

19 used in isolation from each other. There is a Bayesian framework for determining

20 location that uses all the data available, is flexible enough to be used with all tagging

21 techniques, and provides location estimates with built-in measures of uncertainty

22 (Sumner et al. 2009). Bayesian methods allow the contributions of multiple data

23 sources to be decomposed into manageable components. Sumner et al. (2009) showed

24 that many of the problems with uncertainty in archival tag and satellite tracking data

25 can be reduced and quantified using readily available tools.

26 With these mathematical tools applied to the feeding and foraging of top

27 predators, it has been possible to model potential areas where poorly known

28 organisms may be distributed. Indeed, the distribution of many cephalopod,

29 crustacean and fish species in the Southern Ocean, and adjacent waters, is poorly

30 known, particularly during times of the year when research surveys are rare (Xavier et

31 al. 1999; Brandt et al. 2007; Griffiths 2010; Rodhouse et al. in press). Analysing the

32 stomach samples of satellite-tracked higher predators has been advocated as a

33 potential method by which such gaps in knowledge can be filled. This approach

34 showed that wandering albatrosses, Diomedea exulans, foraged in up to three 
1 different water-masses, the Antarctic zone (AZ), the sub-Antarctic zone (SAZ) and

2 the sub-Tropical zone (STZ) (Xavier et al. 2006). A probabilistic mathematical model

3 was applied to the tracking and diet data collected from wandering albatrosses to construct a large scale map of where various prey were captured. Furthermore, robustness and sensitivity analyses were used to test model assumptions about the time spent foraging and relative catch efficiencies and to evaluate potential biases associated with the model. The analysts were able to predict the distributions of a multiple cephalopod, crustacean and fish species (Xavier et al. 2006). This method is likely to be used in the future to predict the distributions of poorly known species, such as large oceanic cephalopods, that are not effectively sampled using nets (Xavier 2003; Xavier et al. 2007; Xavier et al. in press).

In summary, mathematical methods are critically important to studies in marine ecology, including those related to the feeding and foraging ecology of top predators. The many examples range from producing mathematical mixed models to quantify the consumption of prey to providing the algorithms that allow the tracking

\section{The application of mathematics in fisheries management and ecosystem modeling}

\section{Management of Southern Ocean fisheries}

Fishing is one of the main economic activities in the Southern Ocean, alongside science and tourism (Grant et al. 2013b). The responsible management of these fisheries is therefore an important applied ecology problem, which has led to innovative approaches that make extensive use of mathematics and modeling. This section discusses some of these approaches.

Fishing removes animals from an ecosystem. These animals would otherwise continue feeding, growing, reproducing and being fed upon. Such removals can reduce the ability of fished populations to replace themselves and they can have wider impacts on other populations by changing the balance of predators and prey. The Southern Ocean ecosystem has already experienced considerable perturbation as a result of past harvesting which started in the late 1770s and led to localized extinctions of Antarctic fur seals and the commercial extinction of many baleen whale species which had previously consumed an estimated $175 \mathrm{~m} \mathrm{t} \mathrm{yr}^{-1}$ of Antarctic krill Euphausia superba (Laws 1977). 
Antarctic krill is a swarming shrimp-like animal that grows to a maximum of

2 about $6 \mathrm{~cm}$, and is now the target of an expanding fishery (Nicol et al. 2012; Hill

3 2013b). There is also commercial harvesting of various fish species including the

4 high-value Antarctic toothfish, Dissostichus mawsoni, and Patagonian toothfish,

5 Dissostichus eleginoides (Grant et al. 2013b). Fish products are generally sold for

6 direct human consumption while krill is usually processed to produce fishmeal for

7 aquaculture, and oil which is sold as a health supplement (Nicol et al. 2012; Hill

8 2013b). These fisheries are managed by the Commission for the Conservation of

9 Antarctic Marine Living Resources (CCAMLR), which was established in 1982.

10 CCAMLR is responsible for ensuring that fisheries do not cause long-term damage to

11 fished populations or the wider ecosystem. Consequently fisheries management draws

12 on a much broader research effort which aims to understand the dynamics and

13 structure of Southern Ocean ecosystems.

14 One of the key challenges faced by the scientists who advise CCAMLR is

15 uncertainty. Assessments of the state of fished populations are affected by sometimes

16 considerable estimation error and there are no failsafe models to indicate how these

17 populations change in response to fishing, environmental variability and changes in

18 other populations. The uncertainty about how fishing will affect complex ecosystems

19 is even greater. Thus many of the major uses of mathematics in Southern Ocean

20 fisheries management and related research address uncertainty in some form. These

21 uses include producing useful estimates of the state of fished stocks from limited

22 observations (e.g. Agnew et al. 2009), identifying safe catch levels (Hillary et al.

23 2006), understanding ecosystem structure and dynamics (e.g. Hill et al 2012) and

24 evaluating potential risks to the wider ecosystem (e.g. Watters et al. 2013), each of

25 which is discussed in more detail below.

26 CCAMLR uses the precautionary approach to identify catch levels for

27 Southern Ocean fisheries. Hill (2013b), paraphrasing Garcia (1996), states that the

28 precautionary approach aims to "reduce the probability of occurrence of bad events

29 within acceptable limits when the potential for these events is plausible, but not

30 necessarily demonstrated, and the potential costs are significant." Hill (2013b) also

31 suggests that the precautionary approach should reduce the risk of harm to the

32 ecosystem by setting low catch limits and protecting areas from fishing until there is

33 evidence that the risks associated with more intensive fishing are acceptable. 
Analyses and models for the management of fin fish stocks

In order to provide robust management advice to CCAMLR on sustainable catch limits that are consistent with the precautionary approach, fisheries scientists undertake regular (annual or biennial) assessments of exploited fin fish stocks. In common with fisheries management elsewhere, these stock assessments use a vast array of fishery-dependent (e.g. catch rates) and fishery-independent (e.g. local biomass estimates from scientific fishing) data to describe the past and current status of a stock and to project the potential response of the stock to current and future management options (e.g. catch limits). Mathematical techniques lie at the heart of all stock assessments and are used in the construction of assessment models for each

11 fished stock. These models are generally based on population dynamics models that can have varying degrees of complexity. The choice of stock assessment model will depend both on the quality and availability of data on catch and fishing effort and knowledge and availability of information on stock size, geographical stock boundaries, and species-specific life history traits such as growth, natural mortality and sexual maturity. Our understanding of these processes is usually summarized in formal mathematical models (e.g. the von Bertallanfy growth equation) (Candy et al. 2007). demersal longline fisheries in various locations throughout the Southern Ocean (Grant et al. 2013a). Several of these fisheries have taken place for over two decades and consequently assessments can draw on a large amount of fishery-dependent and ecological data. These 'established' fisheries, that include those carried out within the Ross Sea and at a number of sub-Antarctic islands (i.e. South Georgia (Hillary et al. 2006) and the Heard and McDonald islands (Candy,Constable 2008)) are assessed using age - structured, Bayesian 'integrated' stock assessment methods. The input data for these assessments include trawl survey estimates of recruitment, commercial catch at length or age data, standardised catch rate data, mark-recapture data from multi-year tagging programmes, and estimates of natural mortality, growth, the length-weight relationship and maturity data. Given the integrated nature of these assessments in which many datasets are used concurrently to estimate parameters, much attention is given to the statistical weighting of each dataset. Bayesian methods are frequently used in the estimation procedure and uncertainty in the dynamics is 
1 evaluated using Markov Chain Monte Carlo (MCMC) methods (Link,Barker 2010;

2 Magnusson et al. 2012).

A number of smaller fisheries for the two toothfish species exist in the high seas areas of the Southern Ocean, in particular on the seamounts of the Indian Ocean sector for which data on stock size and biological parameters is far more sparse (Agnew et al. 2009). In these new, exploratory and research fishery areas, biomass estimates of the local toothfish population are usually derived from mark recapture data and calculated using the Lincoln -Peterson equation which estimates population size as the product of the numbers of animals captured in each of two events divided by the number that were captured twice (i.e. in both events) (Lincoln 1930). This

11 biomass estimate allows suitable catch limits to be obtained by the application of a 12 conservative exploitation rate. The scientific purpose of these fisheries, which are 13 considered 'data poor', is the collection of high quality data on abundance and the 14 biological characteristics of the stock with the aim of developing fully integrated stock assessments in the near future. As more abundant and robust data become available for these fisheries, more complex population dynamics models are developed and tested in the transition towards a fully integrated assessment.

As with all biological systems there are varying degrees of uncertainty associated with the data used within the stock assessment models. A suite of mathematical procedures has been developed to address this uncertainty in order to improve model fits within the stock assessments of Southern Ocean fin fish populations. These procedures are part of an integrated approach which aims to reduce the uncertainty in the projections used to evaluate management options. The areas of greatest uncertainty have included the estimation of levels of illegal fishing (Agnew,Kirkwood 2005), tagging (Ziegler 2013), cetacean depredation (Clark,Agnew 2010), unaccounted fishing mortality (Webber,Parker 2012), appropriate model weighting for catch-at-age data, catch (Candy 2004) and natural mortality (Candy et

Analyses and models for the management of Antarctic krill stocks

Antarctic krill is a highly abundant species. Atkinson et al. (2009) used various statistical models to estimate the gross growth potential, the amount of new biomass that would be produced by growth each year if all animals survived. These estimates ranged from 342 to $536 \mathrm{Mt} \mathrm{yr}^{-1}$ depending on the model used. For 
1 comparison, total global marine fisheries landings are approximately $80 \mathrm{Mt} \mathrm{yr}^{-1}$ (FAO

2 2012). Of course, Antarctic krill do not achieve their full growth potential because many of them do not survive the year. The vast population of Antarctic krill is continually grazed by an array of predators including pelagic and demersal fish, penguins and other seabirds, whales, seals and even benthic invertebrates. Many of these predators rely on Antarctic krill as their main source of food (Laws 1977; Xavier et al. 2003a; Waluda et al. 2012). For this reason the precautionary approach for Antarctic krill has to consider the indirect effects of fishing on predators since it effectively removes part of their food supply (Grant et al. 2013b). Management which includes such considerations is sometimes known as Ecosystem Based Management

11 (McLeod,Leslie 2009).

In a logistic biomass growth model, the per-capita rate of increase is highest at half of the asymptotic biomass. This leads to the hypothesis that fished populations are most productive if reduced to half of their pre-fishing biomass (Punt,Smith 2001). However, the requirement to explicitly manage potential impacts on Antarctic krill predators led to a more precautionary objective: to ensure that, in the long-term, fishing does not reduce the Antarctic krill population by more than $25 \%$ on average (Constable et al. 2000; Hill et al. 2006). Scientists use a stochastic population projection model to identify catch levels that meet this criterion. The model runs multiple simulations with random deviates in various population parameters (e.g. recruitment, natural mortality, age at maturity) and a range of different catch levels, until it finds the correct level. During this process catch levels are also assessed against another criterion: that the risk of the breeding population falling below $20 \%$ of its initial biomass is no more than $10 \%$. The highest catch level that meets both criteria is selected to manage the fishery (Constable et al. 2000).

Smith et al. (2011) used nine ecosystem dynamics models (that is models of the interacting dynamics of multiple species) to assess the potential impacts of fishing on the rest of the ecosystem. This study considered fisheries for lower trophic level species, such as capelin (Mallotus villosus), herring (Clupea spp.) and anchovies (e.g. Engraulis spp.) in other oceans and did not directly consider the Antarctic krill fishery. Nonetheless it found that allowing a fishery to deplete the biomass of the fished population by no more than $25 \%$ provided reasonable catch levels while achieving "much lower impacts on marine ecosystems" than the higher depletion rates allowed by many fisheries management regimes (Smith et al. 2011). This suggests 
that the general approach used for setting Antarctic krill catch limits might be appropriately precautionary. However, a recent study shows that the catch limits selected using this approach are sensitive to assumed levels of recruitment variability and that recruitment variability in real krill stocks might be higher than that assumed in model projections (Kinzey et al. 2013).

The ecosystem impacts of fishing depend not just on how much biomass of the fished species it removes, but also where it removes biomass from. Although

8 Antarctic krill is widely distributed throughout the Southern Ocean, the vast majority

9 of the catch (83\% of all reported catch to date) (Hill 2013b) is taken from the Scotia 10 Sea and southern Drake Passage (Figure 2) and is in fact concentrated in just $26 \%$ of 11 this area (Grant et al. 2013a). Specifically, fishing occurs in and close to the shallow 12 waters that surround the many islands in this area. Fishing does not generally occur in 13 the more hostile waters of the open ocean where Antarctic krill is still abundant but 14 much less likely to occur in the dense aggregations that the fishery targets (Hill et al. 15 2009). Scientists have used ecosystem dynamics models to assess the risk that such spatially restricted fishing poses to Antarctic krill predators (Plagányi,Butterworth 2012; Watters et al. 2013). These models are spatially resolved to distinguish the various shallow water and open ocean areas and they represent the interactions between Antarctic krill, the fishery, and several groups of competing predators. The exact nature of these interactions is uncertain and there is very little information about past dynamics from which to infer the interactions. Consequently, the modelers did not attempt to devise a single best model to project the consequences of future fishing. Instead they attempted to evaluate the uncertainty in such projections and they translated this uncertainty into estimates of the risks associated with candidate management options (Figure 3).

The approach to this uncertainty about the true nature of the modeled interactions was to use multiple plausible "scenarios" or plausible representations of the system (Hill et al. 2007b). The word "scenario" here means a model and its data (sensu Rademeyer et al. (2007)). The scenarios were based on two different model structures, described in Plagányi and Butterworth (2012) and Watters et al. (2013) and several alternative parameterizations of each model structure. These alternative parameterizations were chosen specifically to bracket key uncertainties. For example, the speed at which Antarctic krill are transported on ocean currents is not known, but the actual speed is likely to lie between a minimum of zero and a maximum of the 
1 speed of passive particles drifting with the currents, which can be deduced from ocean circulation models (Hill et al. 2007a). Watters et al. (2013) developed four parameterizations, each of which combined one of these extreme values for plausible transport speeds with an extreme plausible value for a second key uncertainty affecting the functional relationship between prey availability and the proportion of the predator population that is able to breed. recovery from historic over-harvesting of whales (Croxall 1992). The modelers

11 therefore assessed the marginal effects of Antarctic krill fishing in their projections by 12 comparing them to otherwise identical projections without fishing.

The modelers performed 1001 stochastic projections with each scenario for

Another important innovation recognized the impossibility of predicting with accuracy the future state of the system when it is influenced by multiple interacting drivers including climate variability and change (Kennicutt et al. in press-b), and each evaluated management option (consisting of a catch limit and its spatial distribution amongst modeled spatial units). One of the risks evaluated was the probability of each modeled predator population falling below $75 \%$ of its size in comparable projections without fishing. The models generated several thousand projections per management option with which to calculate this probability. The analysts presented results in the format shown in Figure 3, which shows the coherent accumulation of risk with increasing catch limit, and identifies the least risky spatial distribution (where the catch limit in each spatial unit is proportional to the total predator demand for Antarctic krill in the same unit, labeled "B" in the figure). Hill (2013a) demonstrated that this distribution remains the least risky even if a different reference level (other than 75\%) or scheme for aggregating modeled predator populations is used.

Because managers need to consider the implications of management options for the fished stock, the fishery and predators in multiple areas, the models assessed each of these risks. One important consideration is that various model outputs (e.g. the biomass of the fished stock versus the biomass of one of its predators) have different levels of sensitivity to perturbations in model parameters, suggesting that uncertainties in these parameters could bias comparisons of different risks (Hill,Matthews 2013).

Scientists advising CCAMLR are attempting to develop a feedback management approach for the Antarctic krill fishery that will modify spatially 
1 resolved catch limits in response to information about the local and larger-scale state

2 of the ecosystem. Such an approach is difficult to design and implement when there are multiple objectives for multiple connected areas, and when the system's dynamics are complex and uncertain. Hill and Cannon (2013) used a branch of control theory called model predictive control (MPC) to show that such an approach is feasible in principle and more likely than the current fixed catch limit to simultaneously achieve objectives for the state of the Antarctic krill stock, the state of multiple predator populations and the state of fishery catches (Figure 4). Their study applied MPC to a relatively simple ecosystem dynamics model consisting of two connected areas, each containing a single prey population and a single predator population. Their study also

11 clarified the information requirements of such an approach, which include regular estimates of each of the relevant state variables or, at least, reliable ways of inferring these from the other state estimates and, critically, a clear set of quantitative objectives for each relevant state. Defining such objectives is a major challenge facing CCAMLR and other organizations around the world which seek to implement Ecosystem Based Management (Link et al. 2012; Hill 2013a).

\section{Ecosystem modelling}

Models exploring the interactions between different populations in the ecosystem are useful for devising and assessing Ecosystem Based Management approaches. Some pioneering models of this type were developed for the Southern Ocean ecosystem in the 1980s (Beddington,May 1980, 1982) and the modeling effort that continued to develop since then was the subject of a detailed review by Hill et al (2006). More recent developments include the ecosystem dynamics models described above and a suite of Ecopath-type food web models (Cornejo-Donoso,Antezana 2008; Pinkerton et al. 2010; Hill et al. 2012; Ballerini et al. 2014). Ecopath-type models compile available data on the diet, biomass, and production and consumption rates of the numerous organisms in a particular food web (Polovina 1984). Modelers generally aggregate these organisms in so-called functional groups to reduce the number of model parameters. The modelers then adjust the parameters to satisfy the "mass balance" constraint that the rate of biomass production by any prey group cannot exceed the rate of consumption of that prey biomass by its predators.

One use of Ecopath-type food web models is to identify which functional groups are likely to be strongly affected by changes in the abundance of fished 
1 species (Ulanowicz,Puccia 1990). A related use is to explore the potential responses

2 to a plausible change in one part of the food web. For example, Ballerini et al (2014) converted their model of the winter food web in Marguerite Bay into a bottom-up model, in which consumer biomass increases or decreases with the availability of prey. They increased the modeled biomass of small phytoplankton relative to large phytoplankton while maintaining a constant total phytoplankton biomass. This change is a consistent with recently observed effects (Montes-Hugo et al. 2009). The model predicted reduced production of krill and its predators as a result of this change. Hill et al (2012) reduced krill biomass by $80 \%$ in their model of the South Georgia shelf food web and readjusted the parameters to achieve mass balance. They found that,

11 without compensating effects, this produced a similar decline in the biomass of

12 Antarctic krill predators (fish, seals, penguins and other seabirds). However, a

13 combination of compensating effects (an increase in grazing zooplankton called

14 copepods and a shift in predator diets to take advantage of this increased copepod

15 biomass) could minimize the impacts on Antarctic krill predators. This illustrates the wide range of outcomes that are possible within the current uncertainties on ecological knowledge. Future model development and data collection should aim to better characterize these uncertainties so that it is possible to assess which outcomes are most likely.

The existing suite of food web models for the Southern Ocean provide a valuable resource for comparing the structure and operation of the different regional food-webs (Murphy et al. 2012; Murphy et al. 2013). However, each of the existing regional models was developed by a different modeling team, using patchy and uncertain data, and each model was designed and analyzed to address a unique set of research questions. The differences between the models therefore include real underlying ecological differences, differences due to sampling error in the available data, and differences in the assumptions and subjective decisions made by the various modeling groups. The challenge of distinguishing real ecological differences from these sources of uncertainty is likely to be a major theme in future food web modeling.

In summary, mathematics and modeling are critical to understanding ecosystem structure and dynamics, assessing potential responses to change and developing appropriate fisheries management approaches. CCAMLR's commitment to Ecosystem Based Management and the relative paucity of ecological data for the 
1 Southern Ocean produce some interesting challenges that have led to innovative ecological modeling and analysis. It is practically impossible to identify definitive models of ecosystem structure or dynamics and consequently much of this innovation and many of the ongoing challenges concern the appropriate treatment of uncertainty.

\section{The application of mathematics in Antarctic climate change research} currently receives much attention from scientists, politicians, the media and the general public. Due to the increased rates of environmental change in the Antarctic, considerable research effort has been devoted to modeling the Antarctic atmosphere and the Southern Ocean, and to quantifying physical and biological aspects of change. Most global climate models suggest that regional temperature increases will be greatest and most rapid at higher latitudes (IPCC 2007; Turner et al. 2013a). Rapid increases are already evident over the Antarctic Peninsula where, in the last half century, air temperatures have risen by 2 to $3^{\circ} \mathrm{C}$. To the west of the Antarctic Peninsula sea ice has also declined and ocean temperatures have increased by $1^{\circ} \mathrm{C}$ over 5 decades (Meredith,King 2005; Turner et al. 2013b). Although climate models have successfully helped to build a broad picture of the causes of recent regional change, there are still many gaps in knowledge which affect the ability of climate models to reliably represent the Antarctic climate and the behavior of its ice caps and sea ice. A recent study by Turner and colleagues (2013c) examined the annual cycle and trends in Antarctic sea ice extent (SIE) for 18 climate models. Many of the models have an annual SIE cycle that differs markedly from that observed over the last 30 years. In contrast to the satellite data, which exhibit a slight increase in SIE, the mean SIE of the models over 1979-2005 shows a decrease in each month (Turner et al. 2013c). The models have very large differences in SIE over 1860-2005. The negative SIE trends in most of the model runs over 1979-2005 are a continuation of an earlier decline. There are two major gaps in knowledge that hamper the understanding of the observed increase. Possibly the most important is the limited observational record, in which reliable Antarctic-wide estimates of SIE are only available after approximately 1979. It is therefore very difficult to estimate the size of natural fluctuations in ice extent, which may have contributed to the recent changes. Related to this, the other major gap is in understanding the processes for change that need to be mathematically represented in climate models. At present is seems that the 
1 processes responsible for the observed SIE increase over the last 30 years are not being simulated correctly (Turner et al. 2013c).

Another important prediction of climate change models is changing patterns of precipitation, altering the water input to terrestrial ecosystems. Spatially detailed predictions are not yet available for Antarctica, although water is possibly the single most important factor limiting the distribution of Antarctic terrestrial biota (Convey et al. 2012). In some Antarctic terrestrial systems local environmental changes result in greater energy input and warming, which may be accompanied by a lengthening of the season in which liquid water is available. There is evidence that such changes might increase production, biomass, population size, community complexity and the rate of colonization by previously absent organisms (Bokhorst et al. 2011; Convey et al. 2012). However, at fine scales a decrease or total loss of water input could lead to local extinctions and drastic changes in local ecosystem structure (Convey 2013). Increases in primary biological productivity are already being seen at the margins of the Antarctic continent. These occur in areas of sea-ice loss where recent ice shelf retreat has occurred (Peck et al. 2010). However, Antarctic marine species are generally amongst the least capable of adapting to environmental change. There are three main reasons (Peck 2005): 1- The geographical range over which they can live or disperse is restricted; 2- they have evolved to live in a very specific environment and tolerate only a narrow range of environmental conditions; and 3they have long life histories and consequently slow rates of adaptation. Statistical analysis of experimental research provides evidence that the shallow mega- and macrobenthos are also very sensitive to temperature change (stenothermal). Being warmed by about $5^{\circ} \mathrm{C}$ over periods greater than one month kills most species tested to date, but even smaller temperature rises $\left(2\right.$ or $3^{\circ} \mathrm{C}$ above normal $)$ drastically hinder their ability to perform critical functions, such as avoiding predators (Barnes,Peck 2008). In pelagic waters, changes to key pelagic species have also been notable. Regression analysis indicates a statistically significant relationship between Antarctic krill abundance and winter SIE in the western Scotia Sea, and there were apparent declines in both between the 1970s and 1980s (Atkinson et al. 2004; Turner et al. 2013b). Further SEI declines would likely lead to more changes in the distribution and abundance of Antarctic krill. with statistical models linking ecological processes to environmental variables (e.g. 
1 (Hill et al. 2013; Kawaguchi et al. 2013). For example, Hill et al. (2013) used sea surface temperature projections from sixteen climate models with a statistical model linking Antarctic krill growth (Atkinson et al. 2006) to sea surface temperature. They found that plausible future warming is likely to lead to substantial reductions in the ability of Antarctic krill to produce new biomass throughout the northern Scotia Sea (Figure 5). This is where large populations of Antarctic fur seals, Arctocephalus gazella, penguins and flying seabirds feed on Antarctic krill during the summer breeding season. A reduction in Antarctic krill biomass could result in greater predation on alternative prey and therefore negative impacts on some fish species (Anisimov et al. 2007). As mentioned in the previous section, food web models have

11 been used to assess how such changes could propagate through the food web (Hill et 12 al. 2012; Ballerini et al. 2014). A key issue taken into account by Hill et al. (2013) is that different climate models give different projections, contributing to uncertainty in estimates of future change. Assessing and quantifying this uncertainty is an important mathematical challenge in itself and an active area of research is in developing statistical approaches to combining information from different climate models (Stock et al. 2011; Bracegirdle,Stephenson 2012).

The effects of climate change in populations of top predators, such as penguins, have also been considered (Barbraud,Heimerskirch 2001). Even apparently straightforward tasks, like obtaining an estimate of the total number of penguins, are not easy and require plenty of mathematical tools. As an example, a recent study aimed to estimate the population of emperor penguins, Aptenodytes fosteri, using a single synoptic survey in 2009 (Fretwell et al. 2012). The analysts examined the whole continental coastline of Antarctica using a combination of medium resolution and very high resolution satellite imagery to identify emperor penguin colonies and the area occupied by penguins in each. They obtained actual counts of penguins from eleven ground truthing sites and used robust regression to model the relationship between the number of adult penguins and the area they occupy. They then used the model to estimate of the number of adult penguins at every colony. Finally they scaled this number up to estimate the total population of adults, including those that were absent at the time of the survey, using information about rates of participation in breeding and breeding success (Figure 6). The final estimate of 238,000 adults present, out of a total population of 595,000 compares with the previously published estimate of 135,000-175,000 breeding pairs (Martinez 1992). The revised, 
1 comprehensive estimate of the total breeding population can be used in population models and will provide a baseline for long-term research (Fretwell et al. 2012) which is necessary because global and regional emperor penguin populations are likely to be strongly affected by climate change (Barbraud,Heimerskirch 2001; Jenouvrier et al. 2012; Turner et al. 2013a).

In summary, climate research has always depended upon mathematics to build models and implement analyses. These models and analyses have increased our understanding of the past, and are now being used to project future climate conditions. This is particularly important in the Antarctic where recent changes in some areas are amongst the most extreme on earth. Ecological models are now being linked to

11 climate projections from global climate models, providing a new era of research and

12 bringing disciplines together. Future Antarctic climate research will include foci on

13 characterizing and reducing the uncertainty in model outputs (e.g. by collecting

14 further data and by improving the precision on the variables collected), on improving 15 understanding and representation of climate processes (to improve model performance and the reliability of projections) and on working together with other science disciplines to provide robust evidence on the range of climate impacts, from sea level changes to biodiversity effects, that will inform policy decisions.

\section{Final considerations}

Mathematical analyses are crucial in all areas of Antarctic science and central to addressing issues of global importance. In each scientific area highly specific methods and models have been developed to address particular questions, from the detailed analyses of remotely sensed predator tracking data to the assessment of the outputs from multiple climate models to determine the potential impacts of future global climate change.

A key issue, that is common to all scientific disciplines, is how to deal with the inherent uncertainty associated with the analysis of process interactions in Antarctic systems. Major uncertainties are often the result of limited data availability,

31 due to the difficulties of operating in remote Antarctic systems. However, over the 32 last decade a series of long-term sampling programmes and large-scale international 33 integrated projects (such as Census of Antarctic Marine Life (http://www.caml.aq/), 34 ANDRILL (http://www.andrill.org), GLOBEC (http://www.globec.org/)), and a rapid 
1 increase in the volume of remotely sensed information available, have changed the scale of the data available for analysing these systems. This increase in data availability has led to the development of new methods and algorithms for their efficient collection, validation, storage and analyses. With the continued rapid development of satellite-based and remote observation systems (e.g. ocean drifters and automatic weather stations), and of new methods for genetic analyses of biological systems, a step-change is occurring in the magnitude of data available on all components of Antarctic subsystems. Dealing with these data will require a similar step-change in the use of mathematics in all aspects of Antarctic science.

Many of the issues of global importance in Antarctic science are at the interfaces between traditional disciplines (e.g. biology and physics or oceans and the cryosphere). In many of these areas new methodological and analytical approaches and models are required. For example, addressing questions about how climate change and direct human impacts (such as fishing) will affect ecosystems requires integrated studies that link knowledge of biogeochemical cycles, species and food webs (Murphy et al. 2012; Murphy et al. 2013). This requires integrated whole ecosystem (also termed "end-to-end") analyses at local (10s to $100 \mathrm{~km})$, regional (100s to $100 \mathrm{~km}$ ) and circumpolar scales (10000s km) (Murphy et al. 2012; Murphy,Hofmann 2013). Such whole system integration has become a central focus of international activities in many areas of Antarctic science, and particularly in Southern Ocean studies aimed at linking climate and ecosystem processes (Murphy,Hofmann 2013). There are major theoretical and analytical challenges in developing such integrated analyses and models. These include questions about how different physical, chemical and biological processes link across a range of scales (Murphy et al. 1988), how different model structures can be coupled together to ensure appropriate feedbacks and system behaviour (Murphy et al. 2012) and how to control and characterize the uncertainty that often multiplies as models integrate more processes (Hill et al. 2007b). This will require the development of a wide range of new and innovative mathematical approaches.

\section{Acknowledgements}

We thank Alberto Pinto and his team for organizing such an excellent conference in bringing scientists from a wide range of research disciplines during the 
year on "Mathematics for Planet Earth". We also thank Janet Silk and Peter Fretwell for preparing Figures 2 and 6 respectively. This work has the support of the Ministry of Science and Higher Education in Portugal (Fundação para a Ciência e a Tecnologia) and the research programs CEPH, SCAR AnT-ERA, PROPOLAR and ICED. It is a contribution to the British Antarctic Survey programmes Ecosystems and Climate which are funded by the Natural Environment Research Council.

\section{References}

Agnew, D.J., Edwards, C., Hillary, R., Mitchell, R., Lopez Abellan, L.J.: Status of the coastal stocks of dissostichus spp. In east Antarctica (Divisions 58.4.1 and 58.4.2) CCAMLR Science 16, 71-100 (2009)

Agnew, D.J., Kirkwood, G.P.: A statistical method for estimating the level of IUU fishing: Application to CCAMLR subarea 48.3 CCAMLR Science 12 119-141 (2005)

Anisimov, O.A., Vaughan, D.G., Callaghan, T.V., Furgal, C., Marchant, H., Prowse, T.D., Vilhjálmsson, H., Walsh, J.E.: Polar regions (Arctic and Antarctic). In: Parry, M.L., Canziani, O.F., Palutikof, J.P., van der Linden, P.J., Hanson, C.E. (eds.) Climate Change 2007: Impacts, Adaptation and Vulnerability. Contribution of Working Group II to the Fourth Assessment Report of the Intergovernmental Panel on Climate Change. pp. 653-685. Cambridge University Press, Cambridge (2007)

Atkinson, A., Shreeve, R.S., Hirst, A.G., Rothery, P., Tarling, G.A., Pond, D.W., Korb, R., Murphy, E.J., Watkins, J.L.: Natural growth rates of Antarctic krill (Euphausia superba): II. Predictive models based on food, temperature, body length, sex, and maturity stage. Limnol. Oceanogr. 51, 973-987 (2006)

Atkinson, A., Siegel, V., Pakhomov, E.A., Jessopp, M.J., Loeb, V.: A re-appraisal of the total biomass and annual production of Antarctic krill. Deep Sea Research Part I: Oceanographic Research Papers 56, 727-740 (2009)

Atkinson, A., Siegel, V., Pakhomov, E.A., Rothery, P.: Long-term decline in krill stock and increase in salps within the Southern Ocean. Nature 432, 100-103 (2004)

Ballerini, T., Hofmann, E.E., Ainley, D.G., Daly, K., Marrari, M., Ribic, C.A., Smith, W.O., Steele, J.H.: Productivity and linkages of the food web of the southern region of the Western Antarctic Peninsula continental shelf. Progress in Oceanography 122, 10-29 (2014)

Barbraud, C., Heimerskirch, H.: Emperor penguins and climate change. Nature 411, 183-186 (2001)

Barnes, D.K.A., Peck, L.S.: Vulnerability of Antarctic shelf biodiversity to predicted regional warming. Climate Research 37, 149-163 (2008)

Beddington, J.R., May, R.M.: Maximum sustainable yields in systems subject to harvesting at more than one trophic level. Mathematical Biosciences 51, 261281 (1980)

Beddington, J.R., May, R.M.: The harvesting of interacting species in a natural ecosystem. Scientific American 247, 42-50 (1982) 
Block, B.A., Jonsen, I.D., Jorgensen, S.J., Winship, A.J., Shaffer, S.A., Bograd, S.J., Hazen, E.L., Foley, D.G., Breed, G.A., Harrison, A.L., Ganong, J.E., Swithenbank, A., Castleton, M., Dewar, H., Mate, B.R., Shillinger, G.L., Schaefer, K.M., Benson, S.R., Weise, M.J., Henry, R.W., Costa, D.P.: Tracking apex marine predator movements in a dynamic ocean. Nature 475(7354), 86-90 (2011). doi:10.1038/nature10082

Bokhorst, S., Huiskes, A., Convey, P., Sinclair, B.J., Lebouvier, M., Van de Vijver, B., Wall, D.H.: Microclimate impacts of passive warming methods in Antarctica: implications for climate change studies. Polar Biology 34, 1421$1435(2011)$

Boltovskoy, D.: South Atlantic zooplankton. Backhuys Publishers, Leiden, Netherlands (1999)

Bracegirdle, T.J., Stephenson, D.B.: Higher precision estimates of regional polar warming by ensemble regression of climate model projections. Climate Dynamics 39, 2805-2821 (2012)

Brandt, A., Gooday, A.J., Brandao, S.N., Brix, S., Brokeland, W., Cedhagen, T., Choudhury, M., Cornelius, N., Danis, B., De Mesel, I., Diaz, R.J., Gillan, D.C., Ebbe, B., Howe, J.A., Janussen, D., Kaiser, S., Linse, K., Malyutina, M., Pawlowski, J., Raupach, M., Vanreusel, A.: First insights into the biodiversity and biogeography of the Southern Ocean deep sea. Nature 447(7142), 307-311 (2007)

Candy, S.G.: Modelling catch and effort data using generalised linear models, the tweedie distribution, random vessel effects and random stratum-by-year effects. CCAMLR Science 11, 59-80 (2004)

Candy, S.G., Constable, A.J.: An integrated stock assessment for the Patagonian toothfish (Dissostichus eleginoides) for the Heard and McDonald islands using CASAL. CCAMLR Science 15, 1-34 (2008)

Candy, S.G., Constable, A.J., Lamb, T., Williams, R.: A von Bertalanffy growth model for toothfish at heard island fitted to length-at-age data and compared to observed growth from mark-recapture studies. CCAMLR Science 14, 43-66 (2007)

Ceia, F.R., Phillips, R.A., Ramos, J.A., Cherel, Y., Vieira, R.P., Richard, P., Xavier, J.C.: Short- and long-term consistency in the foraging niche of wandering albatrosses. Marine Biology 159, 1581-1591 (2012)

Cherel, Y., Hobson, K.: Stable isotopes, beaks and predators: a new tool to study the trophic ecology of cephalopods, including giant and colossal squids. Proc R Soc Lond B 272, 1601-1607 (2005)

Clark, J.M., Agnew, D.J.: Estimating the impact of depredation by killer whales and sperm whales on longline fishing for toothfish (Dissostichus eleginoides) around South Georgia. CCAMLR Science 17, 163-178 (2010)

Constable, A.J., De la mare, W.K., Agnew, D.J., Everson, I., Miller, D.: Managing fisheries to conserve the Antarctic marine ecosystem: practical implementation of the Convention on the Conservation of Antarctic Marine Living Resources (CCAMLR). ICES Journal of Marine Science 57, 778-791 (2000)

Constable, A.J., Melbourne-Thomas, J., Corney, S.P., Arrigo, K., Barbraud, C., Barnes, D., Bindoff, N., Boyd, P., Brandt , A., Costa, D.P., Davidson, A., Ducklow, H., Emmerson, L., Fukuchi, M., Gutt, J., Hindell, M.A., Hofmann, E.E., Hosie, G., Iida, T., Jacob, S., Johnston, N.M., Kawaguchi, S., Koubbi, P., Lea, M.-A., Makhado, A., Massom, R., Meiners, K., Meredith, M., 
Murphy, E., Nicol, S., Richerson, K., Riddle, M.J., Rintoul, S.R., Walker Smith Jr., W., Southwell, C., Stark, J.S., Sumner, M., Swadling, K., Takahashi, K., Trathan, P.N., Welsford, D., Weimerskirch, H., Westwood, K., Wienecke, B., Wolf-Gladrow, D., Wright, S., Xavier, J.C., Ziegler, P.: Change in Southern Ocean ecosystems I: How changes in physical habitats directly affect marine biota. Global change biology (in press)

Convey, P.: Antarctic ecosystems. In: Levin, S.A. (ed.) Encyclopedia of Biodiversity. pp. 179-188. Waltham, MA, Academic Press, (2013)

Convey, P., Aitken, S., di Prisco, G., Gill, M.J., Coulson, S.J., Barry, T., Jónsdóttir, I.S., Dang, P.T., Hik, D., Kulkarni, T., Lewis, G.: The impacts of climate change on circumpolar biodiversity. Biodiversity 13, 134-143 (2012)

Cornejo-Donoso, J., Antezana, T.: Preliminary trophic model of the Antarctic Peninsula Ecosystem (Sub-area CCAMLR 48.1). Ecological modelling 218, 117 (2008)

Croxall, J.P.: Southern-Ocean Environmental-Changes - Effects on Seabird, Seal and Whale Populations. Philos. Trans. R. Soc. Lond. Ser. B-Biol. Sci. 338(1285), 319-328 (1992)

Croxall, J.P., Silk, J.R.D., Phillips, R.A., Afanasyev, V., Briggs, D.R.: Global circumnavigations:tracking year-round ranges of nonbreeding albatrosses. Science 307, 249-250 (2005)

Deagle, B.E., Gales, N.J., Evans, K., Jarman, S.N., Robinson, S., Trebilco, R., Hindell, M.A.: Studying seabird diet through genetic analysis of faeces: a case study on macaroni penguins (Eudyptes chrysolophus). PLoS ONE 2, e831 (2007)

Egevang, C., Stenhouse, I.J., Phillips, R.A., Petersen, A., Fox, J.W., Silk, J.R.D.: Tracking of Arctic terns Sterna paradisaea reveals longest animal migration. Proceedings of the National Academy of Sciences (2010)

FAO: The state of world fisheries and aquaculture. Part 1. World review of fisheries and aquaculture. Food and Agriculture Organization of the United Nations, Rome (2012)

Fretwell, P.T., LaRue, M.A., Morin, P., Kooyman, G.L., Wienecke, B., Ratcliffe, N., Fox, A.J., Fleming, A.H., Porter, C., Trathan, P.N.: An emperor penguin population estimate: the first global, synoptic survey of a species from space. PLoS ONE 7, e33751 (2012)

Garcia, S.M.: The precautionary approach to fisheries and its implications for fishery research, technology and management: an updated review. . In: FAO. Precautionary approach to fisheries. Part 2: scientific papers, vol. 350 Part 2. p. 210. FAO Fisheries Technical Paper Rome (1996)

Grant, S.M., Hill, S.L., Fretwell, P.: Spatial distribution of management measures, Antarctic krill catch and Southern Ocean bioregions: implications for conservation planning. CCAMLR Science 20, 1-20 (2013a)

Grant, S.M., Hill, S.L., Trathan, P.N., Murphy, E.J.: Ecosystem services of the Southern Ocean: trade-offs in decision-making. Antarctic Science 25, 603-617 (2013b)

Griffiths, H.J.: Antarctic Marine Biodiversity: What Do We Know About the Distribution of Life in the Southern Ocean? PLoS ONE 5(8), e11683 (2010)

Hazen, E.L., Jorgensen, S., Rykaczewski, R.R., Bograd, S.J., Foley, D.G., Jonsen, I.D., Shaffer, S.A., Dunne, J.P., Costa, D.P., Crowder, L.B., Block, B.A.: Predicted habitat shifts of Pacific top predators in a changing climate. Nature Clim. Change 3(3), 234-238 (2013) 
Hecht, T.: A guide to the otoliths of Southern Ocean fishes. South African Journal of Antarctic Research 17, 2-87 (1987)

Hill, S.L.: From strategic ambiguity to technical reference points in the Antarctic krill fishery: the worst journey in the world? Environmental Conservation 40, 394405 (2013a)

Hill, S.L.: Prospects for a sustainable increase in the availability of long chain omega 3s: Lessons from the Antarctic krill fishery. In: De Meester, F., Watson, R.R., Zibadi, S. (eds.) Omega 6/3 Fatty Acids Functions, Sustainability Strategies and Perspectives pp. 267-296. Humana Press, New York (2013b)

Hill, S.L., Cannon, M.: A potential feedback approach to Ecosystem Based Management: Model Predictive Control of the Antarctic krill fishery. CCAMLR Science 20, 119-138 (2013)

Hill, S.L., Keeble, K., Atkinson, A., Murphy, E.J.: A food web model to explore uncertainties in the South Georgia shelf pelagic ecosystem. Deep-Sea Res. II 59-60, 237-252 (2012)

Hill, S.L., Matthews, J.: The sensitivity of multiple output statistics to input parameters in a krill-predator- fishery ecosystem dynamics model. CCAMLR Science 20, 97-118 (2013)

Hill, S.L., Murphy, E.J., Reid, K., Trathan, P.N., Constable, A.: Modelling Southern Ocean ecosystems: krill, the food-web, and the impacts of fishing. Biological Reviews 81, 581-608 (2006)

Hill, S.L., Phillips, T., Atkinson, A.: Potential Climate Change Effects on the Habitat of Antarctic Krill in the Weddell Quadrant of the Southern Ocean. PLoS ONE 8, e72246 (2013)

Hill, S.L., Reid, K., Thorpe, S.E., Hinke, J., Watters, G.M.: A compilation of parameters for ecosystem dynamics models of the Scotia Sea- Antarctic Peninsula region. CCAMLR Science 14, 1-25 (2007a)

Hill, S.L., Trathan, P.N., Agnew, D.J.: The risk to fishery performance associated with spatially resolved management of Antarctic krill (Euphausia superba) harvesting. ICES Journal of Marine Science 66, 2148-2154 (2009)

Hill, S.L., Watters, G.M., Punt, A.E., McAllister, M.K., Le Quere, C., Turner, J.: Model uncertainty in the ecosystem approach to fisheries. Fish and Fisheries 8, 315-333 (2007b)

Hillary, R.M., Kirkwood, G.P., Agnew, D.J.: An assessment of toothfish in Subarea 48.3 using CASAL. CCAMLR Science 13, 65-95 (2006)

IPCC: Climate Change 2007: Synthesis report. . Contribution of Working Groups I, II and III to the Fourth Assessment Report of the Intergovernmental Panel on Climate Change. IPCC, Geneva, Switzerland, (2007)

Jenouvrier, S., Holland, M., Stroeve, J., Barbraud, C., Weimerskirch, H., Serreze, M., Caswell, H.: Effects of climate change on an emperor penguin population: analysis of coupled demographic and climate models. Global Change Biology 18(9), 2756-2770 (2012)

Jouventin, P., Weimerskirch, H.: Satellite tracking of wandering albatrosses. Nature 343, 746-748 (1990)

Kaiser, B., Zicus, S., Allen, B.: Polar Science and Global Climate: An International Resource for Education \& Outreach. Pearson Custom Publishing (2010)

Karnovsky, N.J., Hobson, K.A., Iverson, S.J.: From lavage to lipids: estimating diets of seabirds. Mar. Ecol.-Prog. Ser. 451, 263-284 (2012) 
Kawaguchi, S., Ishida, A., King, R., Raymond, B., Waller, N., Constable, A., Nicol, S., Wakita, M., Ishimatsu, A.: Risk maps for Antarctic krill under projected Southern Ocean acidification. Nature Clim. Change 3(9), 843-847 (2013) Kennicutt, M.C., Chown, S.L., Cassano, J., Liggett, D., Peck, L.S., Massom, R., Rintoul, S.R., Storey, J., Vaughan, D.G., Wilson, T.J., Allison, I., Ayton, J., Badhe, R., Baeseman, J., Barrett, P.J., Bell, R.E., Bertler, N., Bo, S., Brandt, A., Bromwich, D., Cary, C., Clark, M.S., Convey, P., Costa, E.S., Cowan, D., Deconto, R., Dunbar, R., Elfring, C., Escutia, C., Francis, J., Fricker, H.A., Fukuchi, M., Gilbert, N., Gutt, J., Havermans, C., Hik, D., Hosie, G., Jones, C., Kim, Y.D., Le Maho, Y., Lee, S.H., Leppe, M., Leitchenkov, G., Lipenkov, X.L.V., Lochte, K., López-Martínez, J., Lüdecke, C., Lyons, W., Marenssi, S., Miller, H., Morozova, P., Naish, T., Nayak, S., Ravindra, R., Retamales, J., Ricci, C.A., Rogan-Finnemore, M., Ropert-Coudert, Y., Samah, A.A., Sanson, L., Scambos, T., Schloss, I., Shiraishi, K., Siegert, M.J., Simões, J., Sparrow, M.D., Storey, B., Wall, D., Walsh, J.C., Wilson, G., Winther, J.G., Xavier, J.C., Yang, H., Sutherland, W.J.: Future directions in Antarctic and Southern Ocean science: 1st SCAR Horizon Scan. Antarctic Science (in press-a)

Kennicutt, M.C.I., Chown, S.L., Cassano, J., Liggett, D., Massom, R., Peck, L., Rintoul, S.R., Storey, J., Vaughan, D.G., Wilson, T., Sutherland, W.J.: Antarctic and Southern Ocean Science in the 21st Century. Nature (in press-b)

Kinzey, D., Watters, G., Reiss, C.S.: Effects of recruitment variability and natural mortality on generalised yield model projections and the CCAMLR decision rules for Antarctic krill. CCAMLR Science 20, 81-96 (2013)

Krupnik, I., Allison, I., Bell, R., Cutler, P., Hik, D., López-Martinez, J., Rachold, V., Sarukhanian, E., Summerhayes, C.: Understanding earth's polar challenges : International Polar Year 2007-2008, vol. no. 1. University of the Arctic, Rovaniemi, Finland/CCI Press (2011)

Laws, R.M.: Seals and Whales of the Southern Ocean. Phil.Trans.R.Soc.Lond.B 279, 81-96 (1977)

Lincoln, F.C.: Calculating waterfowl abundance on the basis of banding returns, vol. 118. Cir. U.S. Department of Agriculture, (1930)

Link, J.S., Ihde, T.F., Harvey, C.J., Gaichas, S.K., Field, J.C., Brodziak, J.K.T., Townsend, H.M., Peterman, R.M.: Dealing with uncertainty in ecosystem models: The paradox of use for living resources. Progress in Oceanography 102, 102-114 (2012)

Link, W.A., Barker, R.J.: Bayesian Inference with Ecological Applications. Academic Press, London (2010)

Magnusson, A., Punt, A., Hilborn, R.: Measuring uncertainty in fisheries stock assessment: the delta method, bootstrap, and MCMC. Fish and Fisheries 14(3) (2012)

Martinez, I.: Emperor penguin In Handbook of the Birds of the World vol. 1. Lynx Edicions, Barcelona (1992)

McLeod, K.L., Leslie, H.M.: Why ecosystem-based management? In: McLeod, K., Leslie, H. (eds.) Ecosystem-based management for the oceans. pp. 3-12. Island Press, Washington DC (2009)

Meredith, M.P., King, J.C.: Rapid climate change in the ocean west of the Antarctic Peninsula during the second half of the $20^{\text {th }}$ century. Geophys. Res. Lett. 32, L19604 (2005) 
Montes-Hugo, M., Doney, S.C., Ducklow, H.W., Fraser, W., Martinson, D., Stammerjohn, S.E., Schofield, O.: Recent changes in phytoplankton communities associated with rapid regional climate change along the Western Antarctic Peninsula. Science 323, 1470-1473 (2009)

Murphy, E.J., Cavanagh, R.D., Hofmann, E.E., Hill, S.L., Constable, A.J., Costa, D.P., Pinkerton, M.H., Johnston, N.M., Trathan, P.N., Klinck, J.M., WolfGladrow, D.A., Daly, K.L., Maury, O., Doney, S.C.: Developing integrated models of Southern Ocean food webs: including ecological complexity, accounting for uncertainty and the importance of scale. Progress in Oceanography 102, 74-92 (2012)

Murphy, E.J., Hofmann, E.E.: End-to-end in Southern Ocean ecosystems. Current opinion in Environmental Sustainability (2013)

Murphy, E.J., Hofmann, E.E., Watkins, J.L., Johnston, N.M., Piñones, A., Ballerini, T., Hill, S.L., Trathan, P.N., Tarling, G.A., Cavanagh, R.A., Young, E.F., Thorpe, S.E., Fretwell, P.: Comparison of the structure and function of Southern Ocean regional ecosystems: The Antarctic Peninsula and South Georgia. Journal of Marine Systems 109-110(0), 22-42 (2013)

Murphy, E.J., Morris, D.J., Watkins, J.L., Priddle, J.: Scales of Interaction Between Antarctic Krill and the Environment. In: Sahrhage, D. (ed.) Antarctic Ocean and Resources Variability. pp. 120-130. Springer Berlin Heidelberg, (1988)

Nevitt, G.A., Losekoot, M., Weimerskirch, H.: Evidence for olfactory search in wandering albatross, Diomedea exulans. Proc. Nat. Acad. Sci. USA 105, 4576-4581 (2008)

Nicol, S., Foster, J., S., K.: The fishery for Antarctic krill-recent developments. Fish and Fisheries 13, 30-40 (2012)

Orr, J.C., Fabry, V.J., Aumont, O., Bopp, L., Doney, S.C., Feely, R.A., Gnanadesikan, A., Gruber, N., Ishida, A., Joos, F., Key, R.M., Lindsay, K., Maier-Reimer, E., Matear, R., Monfray, P., Mouchet, A., Najjar, R.G., Plattner, G.-K., Rodgers, K.B., Sabine, C.L., Sarmiento, J.L., Schlitzer, R., Slater, R.D., Totterdell, I.J., Weirig, M.-F., Yamanaka, Y., Yool, A.: Anthropogenic ocean acidification over the twenty-first century and its impact on calcifying organisms. Nature 437(7059), 681-686 (2005)

Parmelee, D.F., Parmelee, J.M., Fuller, M.R.: Ornithological investigations and Palmer Station: the first long-distance tracking of seabirds by satellites. Antarctic Journal of the United States 20, 162-163 (1985)

Parnell, A.C., Inger, R., Bearhop, S., Jackson, A.L.: Source partitioning using stable isotopes: coping with too much variation. PLoS ONE 5, e9672 (2010)

Peck, L.S.: Prospects for surviving climate change in Antarctic aquatic species. . Frontiers in Zoology 2, 2-9 (2005)

Peck, L.S., Barnes, D.K.A., Cook, A.J., Fleming, A.H., Clarke, A.: Negative feedback in the cold: ice retreat produces new carbon sinks in Antarctica. Global Change Biology 16(9), 2614-2623 (2010). doi:10.1111/j.13652486.2009.02071.x

Phillips, R.A., Croxall, J.P., Silk, J.R.D., Briggs, D.R.: Foraging ecology of albatrosses and petrels from South Georgia: two decades of insights from tracking technologies. Aquatic Conservation: Marine and Freshwater Ecosystems 17, S6-S21 (2008)

Phillips, R.A., Silk, J.R.D., Croxall, J.P., Afanasyev, V., Briggs, D.R.: Accuracy of geolocation estimates for flying seabirds. Marine Ecology Progress Series 266, 265-272 (2004) 
Phillips, R.A., Xavier, J.C., Croxall, J.P.: Effects of satellite transmitters on albatrosses and petrels. The Auk 120(4), 1082-1090 (2003)

Pinkerton, M.H., Bradford-Grieve, J.M., Hanchet, S.M.: A balanced model of the food web of the Ross Sea, Antarctica. CCAMLR Science 17, 1-31 (2010)

Plagányi, É.E., Butterworth, D.S.: The Scotia Sea krill fishery and its possible impacts on dependent predators: modeling localized depletion of prey. Ecological Applications 22, 748-761 (2012)

Polovina, J.J.: Model of a coral reef ecosystem I. The ECOPATH model and its application to French Frigate Shoals. Coral Reefs 3, 1-11 (1984)

Prince, P.A., Wood, A.G., Barton, T.R., Croxall, J.P.: Satellite-tracking wandering albatrosses Diomedea exulans in the South Atlantic. Antarctic Science 4, 3136 (1992)

Punt, A.E., Smith, A.D.M.: The gospel of maximum sustainable yield in fisheries management: birth, crucifixion and reincarnation. In: Reynolds, J.D., Mace, G.M., Redford, K.H., Robinson, J.G. (eds.) Conservation of exploited species. pp. 41-66. Cambridge University Press, Cambridge (2001)

Rademeyer, R.A., Plagányi, É.E., Butterworth, D.S.: Tips and tricks in designing management procedures. ICES Journal of Marine Science 64, 618-625 (2007)

Ramos, R., Gonzalez-Solis, J.: Trace me if you can: the use of intrinsic biogeochemical markers in marine top predators. Frontiers in Ecology and the Environment 10(5), 258-266 (2012)

Ratcliffe, N., Trathan, P.N.: A review of the diet and foraging movements of penguins breeding within the CCAMLR area. In. BAS, Cambridge unpbl. data, (2011)

Reid, K.: A guide to the use of otoliths in the study of predators at South Georgia. British Antarctic Survey, Cambridge (1996)

Rignot, E., Bamber, J.L., Van Den Broeke, M.R., Davis, C., Li, Y.H., Van De Berg, W.J., Van Meijgaard, E.: Recent Antarctic ice mass loss from radar interferometry and regional climate modelling. Nature Geoscience 1, 106-110 (2008)

Rodhouse, P.G., Xavier, J.C., Griffiths, H.: Southern Ocean squid. In: De Broyer, C., Koubbi, P., Griffiths, H., Danis, B., David, B., Grant, S., Gutt, J., Held, C., Hosie, G., Huettmann, F., Post, A., Raymond, B., Ropert-Coudert, Y., van de Putte, A. (eds.) The CAML / SCAR-MarBIN Biogeographic Atlas of the Southern Ocean. p. 400. Scientific Committee on Antarctic Research, Cambridge (in press)

Sarmiento, J.L., Gruber, N., Brzezinski, M.A., Dunne, J.P.: High-latitude controls of thermocline nutrients and low latitude biological productivity. Nature 427(6969), 56-60 (2004)

Smetacek, V., Nicol, S.: Polar ocean ecosystems in a changing world. Nature 437, 362-368 (2005)

Smith, A.D., Brown, C.J., Bulman, C.M., Fulton, E.A., Johnson, P., Kaplan, I.C., Lozano-Montes, H., Mackinson, S., Marzloff, M., Shannon, L.J., Shin, Y.J., Tam, J.: Impacts of fishing low-trophic level species on marine ecosystems. Science 333, 1147-1150 (2011)

Stock, C.A., Alexander, M.A., Bond, N.A., Brander, K.M., Cheung, W.W.: On the use of IPCC-class models to assess the impact of climate on living marine resources. Progress in Oceanography 88, 1-27 (2011)

Sumner, M.D., Wotherspoon, S.J., Hindell, M.A.: Bayesian estimation of animal movement from archival and satellite tags. PLoS ONE 4, e7324 (2009) 
Tavares, S., Xavier, J.C., Phillips, R.P., Pereira, M.E., Pardal, M.A.: Influence of age, sex and breeding status on mercury accumulation patterns in wandering albatrosses Diomedea exulans. Environmental pollution 181, 315-320 (2013)

Turner, J., Barrand, N.E., Bracegirdle, T.J., Convey, P., Hodgson, D.A., Jarvis, M., Jenkins, A., Marshall, G., Meredith, M.P., Roscoe, H., Shanklin, J., French, J., Goosse, H., Guglielmin, M., Gutt, J., Jacobs, S., Kennicutt, M.C.I., MassonDelmotte, V., Mayewski, P., Navarro, F., Robinson, S., Scambos, T., Sparrow, M., Summerhayes, C., Speer, K., Klepikov, A.: Antarctic climate change and the environment: an update. Polar Record FirstView, 1-23 (2013a)

Turner, J., Bindschadler, R., Convey, P., di Prisco, G., Fahrbach, E., Gutt, J., Hodgson, D., Mayewski, P., Summerhayes, C.: Antarctic climate change and the environment. Scientific Committee for Antarctic Research, Cambridge, UK, (2009)

Turner, J., Maksym, T., Phillips, T., Marshall, G.J., Meredith, M.P.: The impact of changes in sea ice advance on the large winter warming on the western Antarctic Peninsula. International Journal of Climatology 33(4), 852-861 (2013b)

Turner, J., Thomas, J.B., Phillips, T., Marshall, G.J., Hosking, J.S.: An initial assessment of antarctic sea ice extent in the cmip5 models. J. Climate 26, 1473-1484 (2013c)

Ulanowicz, R.E., Puccia, C.J.: Mixed trophic impacts in ecosystems. Coenoses 5, 716 (1990)

Walton, D.: Antarctica: Global science from a frozen continent. Cambridge University Press, (2013)

Walton, D., Xavier, J.C., May, I., Huffman, L.: Polar Educators International - a new initiative for schools. Antarctic Science 25, 473 (2013)

Waluda, C.M., Hill, S.L., Peat, H.J., Trathan, P.N.: Diet variability and reproductive performance of macaroni penguins (Eudyptes chrysolophus) at Bird Island, South Georgia. Marine Ecology Progress Series 466, 261-274 (2012)

Watters, G.M., Hill, S.L., Hinke, J., Matthews, J., Reid, K.: Decision making for ecosystem based management: evaluating options for a krill fishery with an ecosystem dynamics model. Ecological Applications 23, 710-725 (2013)

Webber, D.N., Parker, S.J.: Estimating unaccounted fishing mortality in the Ross sea region and Amundsen sea (CCAMLR subareas 88.1 and 88.2) bottom longline fisheries targeting Antarctic toothfish. CCAMLR Science 19, 17-30 (2012)

Weimerskirch, H., Bonadonna, F., Bailleul, F., Mabille, G., Dell'Omo, G., Lipp, H.P.: GPS tracking of foraging albatrosses. Science 295, 1259-1259 (2002)

Wilson, R.P., Grémillet, D., Syder, J., Kierspel, M.A.M., Garthe, S., Weimerskirch, H., Schafer-Neth, C., Scolaro, J.A., Bost, C.-A., Plotz, J., Nel, D.C.: Remotesensing systems and seabirds: their use, abuse and potential for measuring marine environmental variables. Marine Ecology Progress Series 228, 241261 (2002)

Xavier, J.C.: Predator-prey interactions between albatrosses and cephalopods at South Georgia. University of Cambridge (2003)

Xavier, J.C., Allcock, L., Cherel, Y., Lipinski, M.R., Gomes-Pereira, J.N., Pierce, G., Rodhouse, P.G.K., Rosa, R., Shea, L., Strugnell, J., Vidal, E., Villanueva, R., Ziegler, A.: Future challenges in cephalopod research. Journal of the Marine Biological Association of the UK (in press)

Xavier, J.C., Barbosa, A., Agusti, S., Alonso-Sáez, L., Alvito, P., Ameneiro, J., Avila, C., Baeta, A., Canário, A., Carmona, R., Catry, P., Ceia, F., Clark, M.S., 
Cristobo, F.J., Cruz, B., Duarte, C.M., Figuerola, B., Gili, J.-M., Gonçalves, A.R., Gordillo, F.J.L., Granadeiro, J.P., Guerreiro, M., Isla, E., Jiménez, C., López-González, P.J., Lourenço, S., Marques, J.C., Moreira, E., Mota, A.M., Nogueira, M., Núñez-Pons, L., Orejas, C., Paiva, V.H., Palanques, A., Pearson, G.A., Pedrós-Alió, C., Peña Cantero, A.L., Power, D.M., Ramos, J.A., Rossi, S., Seco, J., Sañe, E., Serrão, E.A., Taboada, S., Tavares, S., Teixidó, N., Vaqué, D., Valente, T., Vázquez, E., Vieira, R., B., V.: Polar marine biology science in Portugal and Spain: Recent advances and future perspectives. Journal of Sea Research 83, 9-29 (2013a)

Xavier, J.C., Cherel, Y.: Cephalopod beak guide for the Southern Ocean. British Antarctic Survey, (2009)

Xavier, J.C., Cherel, Y., Roberts, J., Piatkowski, U.: How do cephalopods become available to seabirds: can fish gut contents from tuna fishing vessels be a major food source of deep-dwelling cephalopods? ICES J. of Marine Science 70, 46-49 (2013b)

Xavier, J.C., Clarke, M.R., Magalhães, M.C., Stowasser, G., Blanco, C., Cherel, Y.: Current status of using beaks to identify cephalopods: III international workshop and training course on cephalopod beaks, Faial Island, Azores, April 2007. Arquipélago - Life and Marine Sciences 24, 41-48 (2007)

Xavier, J.C., Croxall, J.P., Cresswell, K.A.: Boluses: an effective method to assess the proportions of cephalopods in the diet of albatrosses. Auk 122, 1182-1190 (2005)

Xavier, J.C., Croxall, J.P., Reid, K.: Inter-annual variation in the diet of two albatross species breeding at South Georgia: implications for breeding performance. Ibis 145, 593-610 (2003a)

Xavier, J.C., Croxall, J.P., Trathan, P.N., Rodhouse, P.G.: Inter-annual variation in the cephalopod component of the diet of wandering albatrosses Diomedea exulans breeding at Bird Island, South Georgia. Marine Biology 142, 611-622 (2003b)

Xavier, J.C., Geraint, G.A., Croxall, J.P.: Determining large scale distribution of pelagic cephalopods, fish and crustaceans in the South Atlantic from wandering albatross (Diomedea exulans) foraging data. Ecography 29, 260272 (2006)

Xavier, J.C., Phillips, R.A., Cherel, Y.: Cephalopods in marine predator diet assessments: why identifying upper and lower beaks is important. ICES J. of Marine Science 68, 1857-1864 (2011)

Xavier, J.C., Rodhouse, P.G., Trathan, P.N., Wood, A.G.: A Geographical Information System (GIS) atlas of cephalopod distribution in the Southern Ocean. Antarctic Science 11(1), 61-62 (1999)

Xavier, J.C., Trathan, P.N., Croxall, J.P., Wood, A.G., Podestá, G.P., Rodhouse, P.G.: Foraging ecology and interactions with fisheries of wandering albatrosses at South Georgia. Fisheries Oceanography 13, 324-344 (2004)

Ziegler, P.E.: Influence of data quality and quantity from a multiyear tagging program on an integrated fish stock assessment. Canadian Journal of Fisheries and Aquatic Sciences 70, 1031-1045 (2013) 


\section{Figures}

Figure 1. Penguins, such as macaroni penguins, are important components of the Southern Ocean ecosystem and are difficult to directly observe because of the remote and hostile conditions in which they live and the considerable distances that they travel. Nonetheless Antarctic scientists have used mathematical tools to develop ways to study their behavior and ecology in the wild, including their feeding and foraging ecology (photo by José Xavier).

Figure 2. The Antarctic continent and the Southern Ocean which surrounds it. The Polar Front is the approximate northern limit of the Southern Ocean ecosystem. Antarctic krill is a major component of this ecosystem, the main prey item for a diverse suite of predators and the focus of a developing fishery. Although Antarctic krill fishing is permitted in much of the Southern Ocean, the vast majority of the catch to date has been taken in the Scotia Sea and southern Drake Passage region ((Nicol et al. 2012; Hill 2013b). Antarctic krill abundance in this region is correlated with September sea ice extent (Atkinson et al. 2004), the average position of which (19792004) is shown.

Figure 3. An assessment of risk based on the results of model projections with intentionally high levels of uncertainty (Watters et al. 2013, Hill 2013a). The model represents multiple populations of each type of predator (whales, seals, fish and penguins), which are shown as colour-coded lines in the figure. Population sizes above a threshold level (in this case, $75 \%$ of its size in projections with no fishing) indicate that the ecosystem is healthy. "Risk to ecosystem health" is the proportion of simulations in which the projected predator population size was below the threshold. The figure shows how this risk increases with catch level ("proportion of regional catch limit") and varies between three alternative spatial distributions of the catch limit (labeled A to $\mathrm{C}$ ). The purpose of this risk assessment was to advise policymakers on the potential effects of the three alternative spatial distributions of two different catch limits (vertical dotted lines).

Figure 4. The biomass of a modeled krill-like species in 500 stochastic simulations using two different harvest control strategies: (A) a fixed catch limit, as is currently used to manage the Antarctic krill fishery, and (B) a feedback method which uses model predictive control (MPC) to adjust catch limits in response to information 
1 about the harvested stock and its predators (Hill and Cannon 2013). The green line

2 highlights a single simulation. The strategies aim to achieve a state indicated by the 3 solid horizontal line (known as the "target reference point") and to avoid states below 4 the dashed horizontal line (known as the "limit reference point").

Figure 5. The results of a study which used projections from multiple climate models to drive a statistical model of Antarctic krill growth (Hill et al. 2013). The figure

8 shows the spatial pattern of projected change in gross growth potential (GGP), an 9 indicator of new biomass production, from 1997-2011 to 2070-2099. The growth 10 model represents the influence of both temperature and food availability. The panels 11 are arranged from top to bottom in order of increasing projected warming from three different representative control pathways (RCPs, which control the radiative forcing and hence warming in climate models). The figures are arranged from left to right in order of increasing final food availability indicated by chlorophyll concentration, including a 50\% decrease and a 50\% increase from current (observed) concentrations. Additionally, the central column shows the degree of agreement between climate models: Cells where $50 \%$ or more of the models project significant GGP change are highlighted with stippling if $90 \%$ or more of models agree on the sign of the change, and are highlighted with hatched lines if fewer than $90 \%$ agree.

Figure 6. The location of all known emperor penguin colonies in Antarctica and the estimated number of adults present in each at the time of a 2009 satellite survey (Fretwell et al. 2012). 


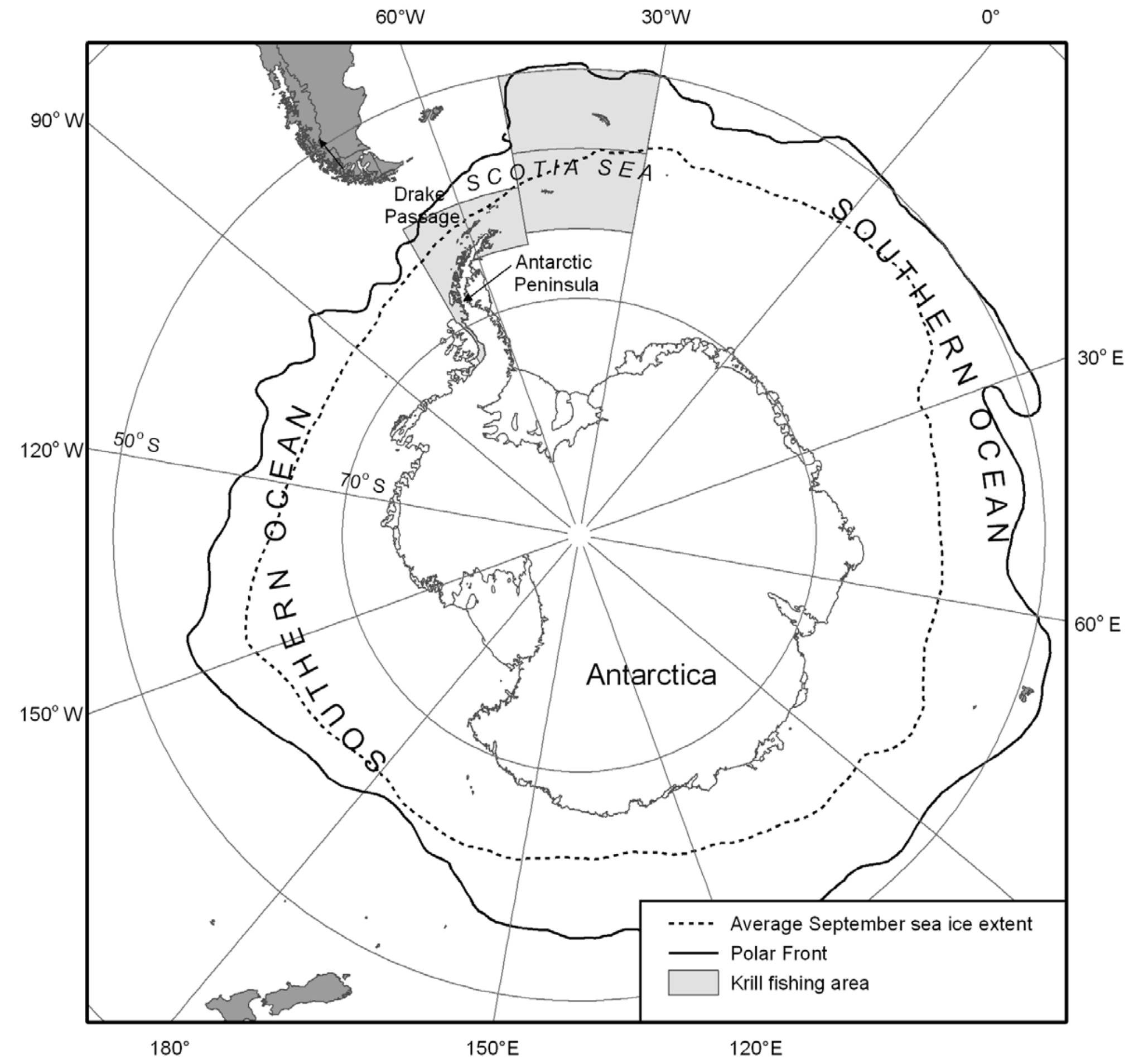




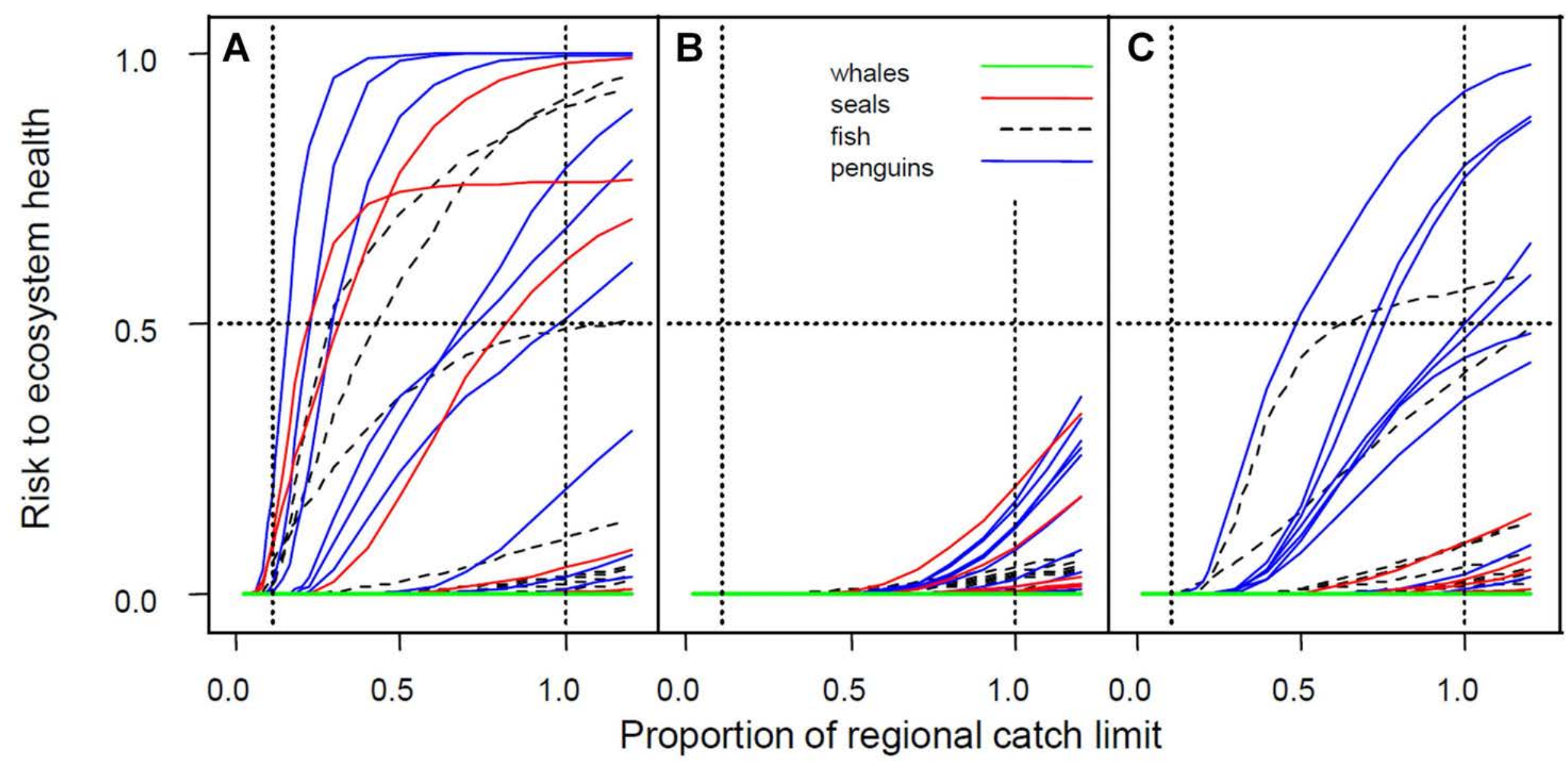




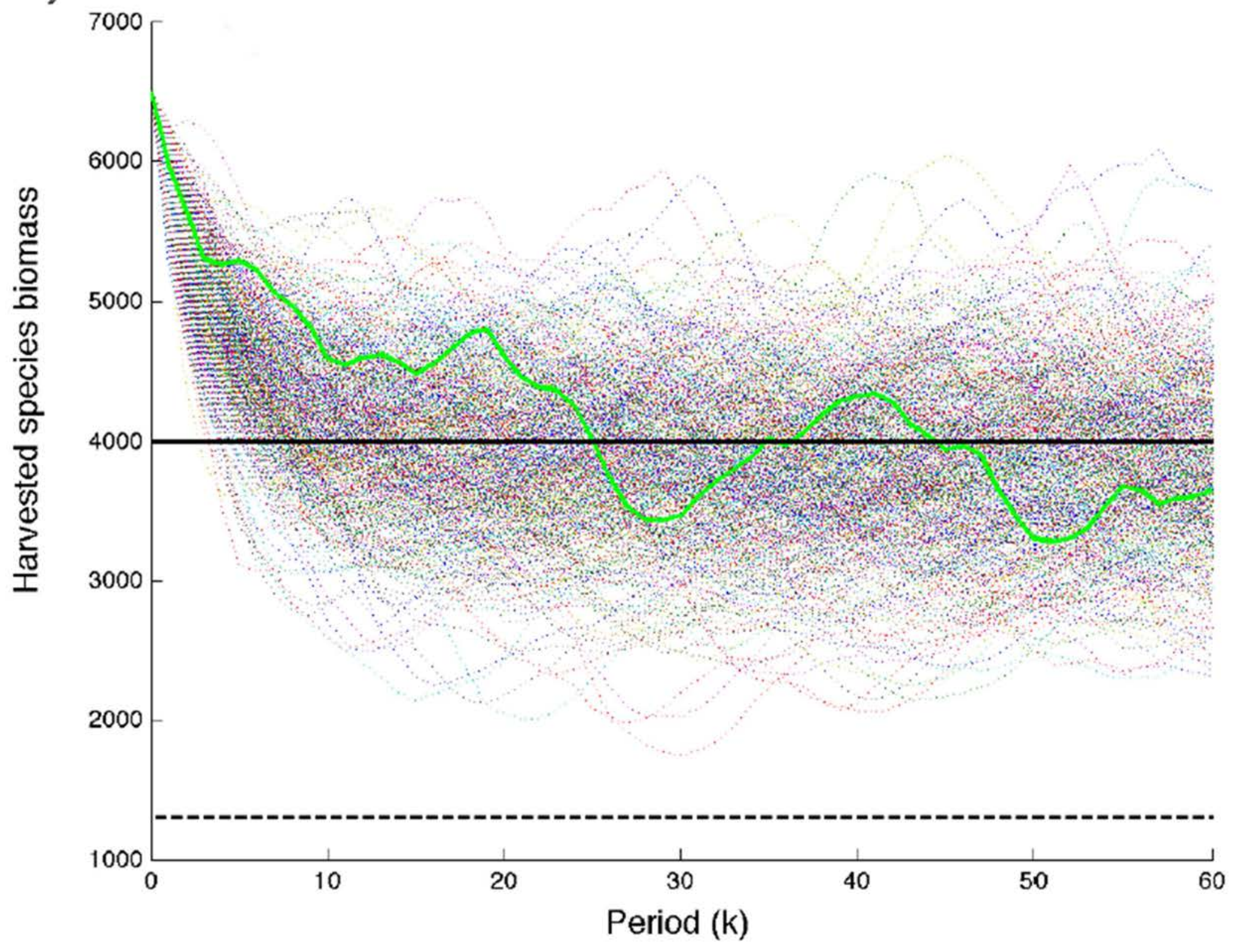




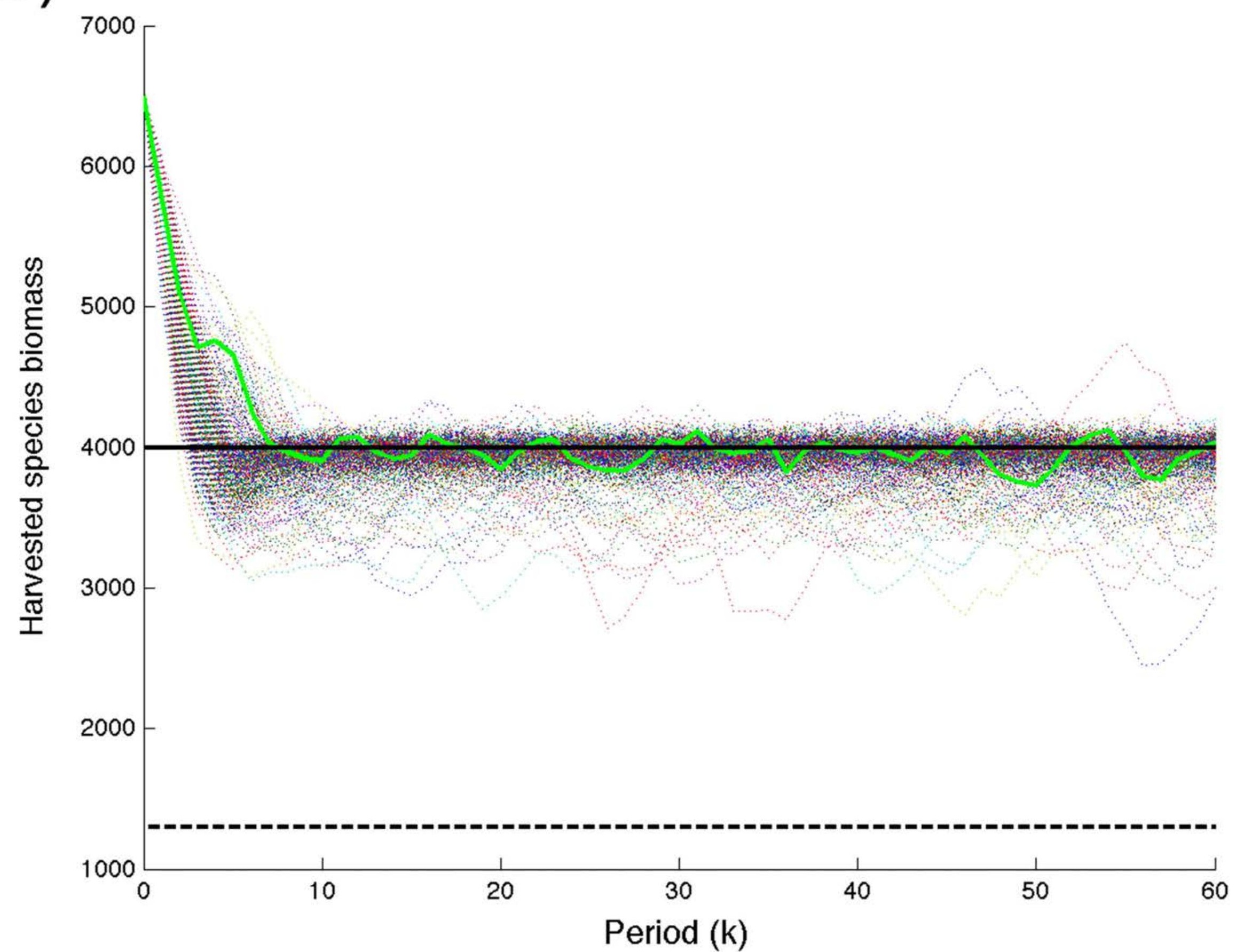


observed chlorophyll - 50\% observed chlorophyll-a observed chlorophyll $+50 \%$

RCP2.6
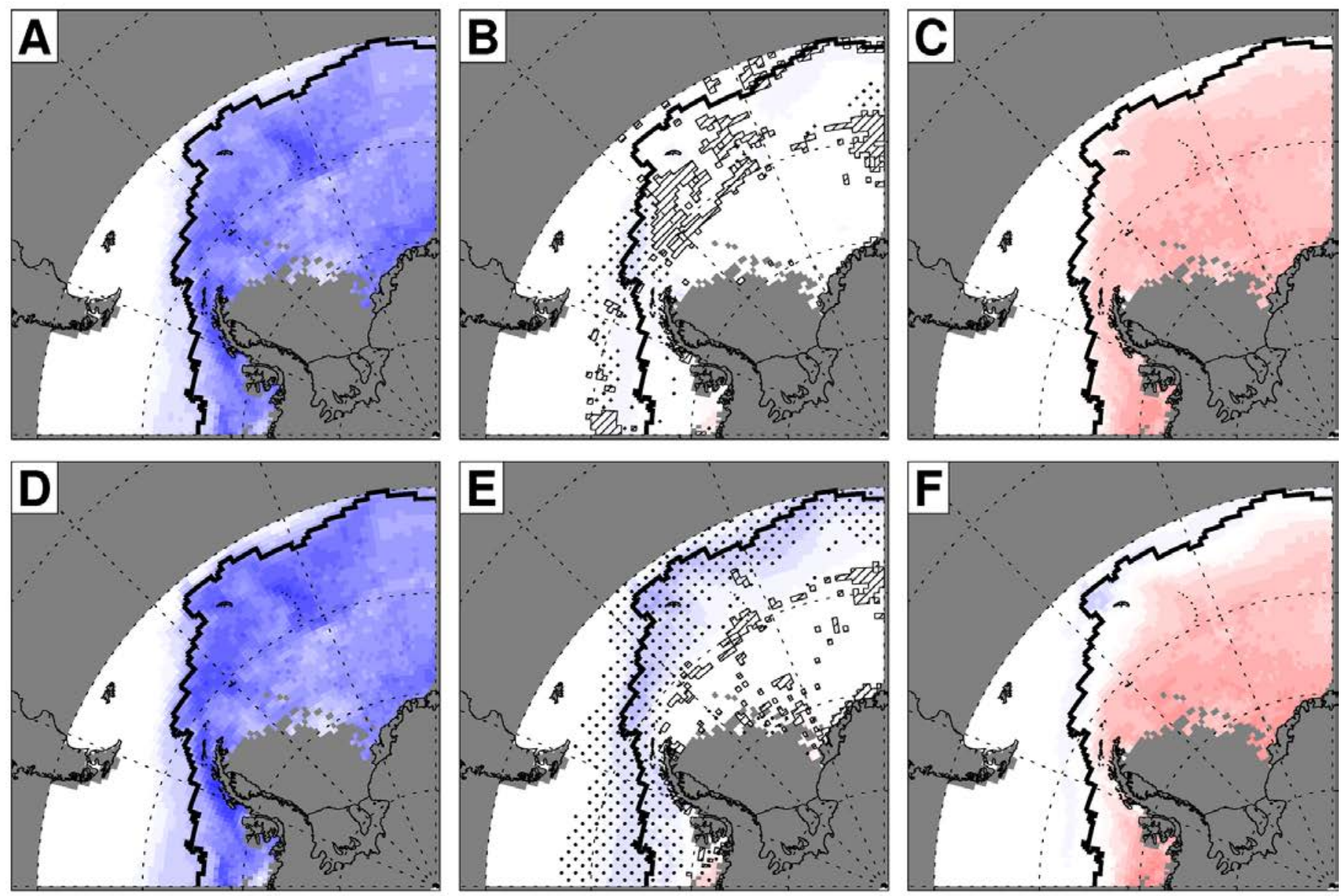

RCP4.5
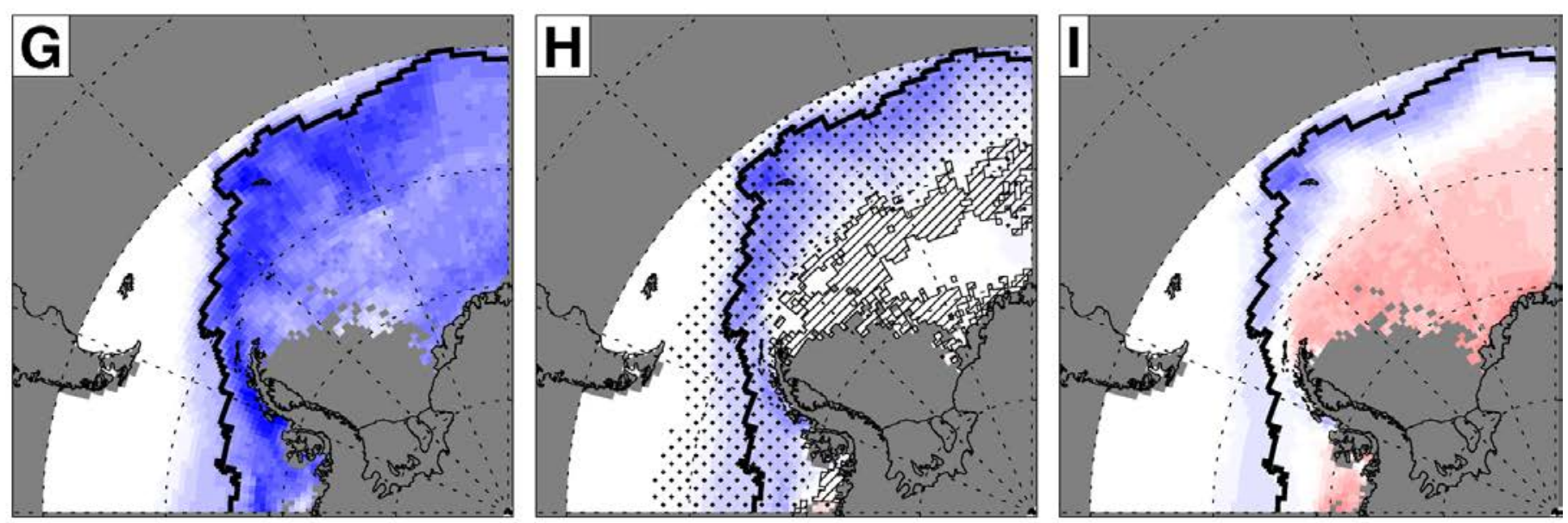

GGP

change

$\begin{array}{lllllllllllllll}-1.4 & -1.2 & -1 & -0.8 & -0.6 & -0.4 & -0.2 & 0 & 0.2 & 0.4 & 0.6 & 0.8 & 1 & 1.2 & 1.4\end{array}$

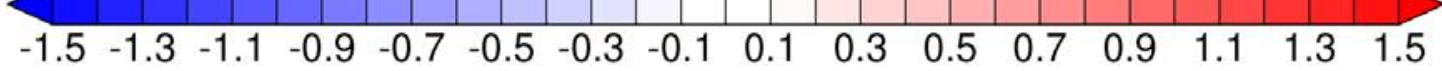




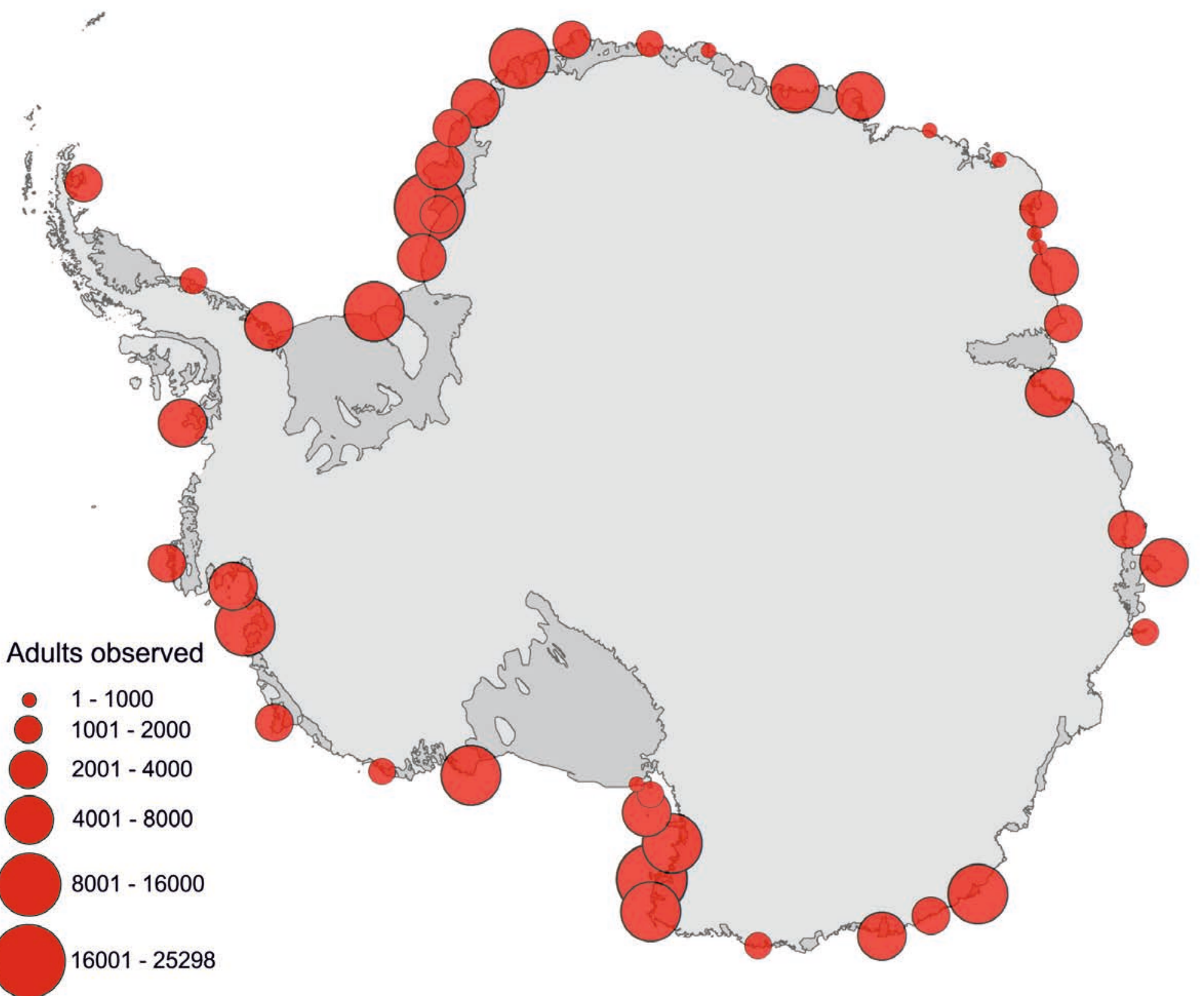

